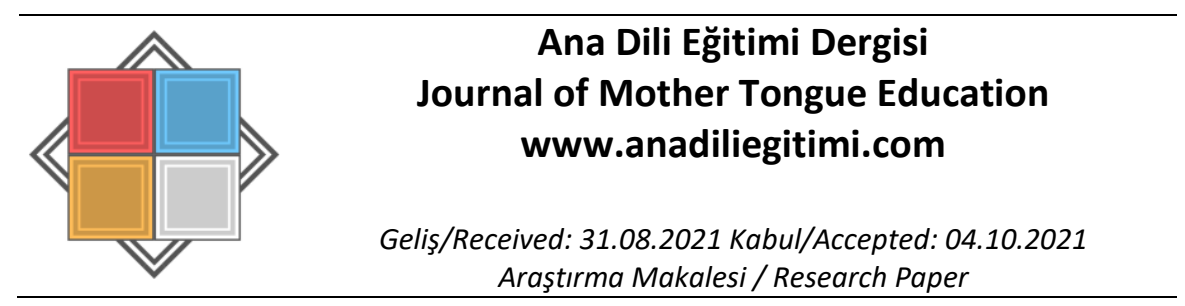

\title{
Türkçe Öğretmenlerinin Görüşlerine Göre Yazma Eğitimini Olumsuz Etkileyen Unsurlar ve Çözüm Önerileri*
}

\author{
Halil KOKKOKOĞLU** \\ Yusuf DOĞAN ${ }^{* * *}$
}

\begin{abstract}
Öz
Araştırmanın amacı, Türkçe öğretmenlerinin yazma eğitimiyle ilgili karşılaştıkları sorunları ve bu sorunlara yönelik çözüm önerilerinin neler olduğunu tespit etmektir. Bu amaç doğrultusunda araştırma, nitel araştırma yöntemlerinden olgubilim (fenomenoloji) deseni çerçevesinde yapılandırılmıştır. Araştırmanın katılımcılarını Millî Eğitim Bakanlığı bünyesinde görev yapan 25 Türkçe öğretmeni oluşturmaktadır. Katılımcıların görüşlerini tespit etmek için yarı yapılandırılmış görüşme formu kullanılmıştır. Elde edilen bulgular içerik analizine tabi tutularak irdelenmiş ve kategoriler hâlinde sunulmuştur. Araştırma sonucunda elde edilen bulgulara göre yazma eğitimi sürecini olumsuz etkileyen unsurların "öğrenci; aile, okul ve çevre; ders kitabı; ders saati ve müfredat; $M E B$ ve eğitim sistemi; öğretmen; öğrencilerin ilkokul eğitimi; öğretmenlerin lisans eğitimi" olmak üzere sekiz farklı nedene dayandığı tespit edilmiştir. Öğretmenlerin yazma becerisini geliştirmek için sundukları önerilerin ise "öğrenci; uygulama, etkinlik; aile, okul ve çevre; ders kitabı; ders saati ve müfredat; MEB ve eğitim sistemi; öğretmen; öğrencilerin ilkokul eğitimi; öğretmenlerin lisans eğitimi” olmak üzere dokuz farklı kategoride toplandığı görülmüştür. Görüşme yapılan öğretmenler, yazma eğitimini olumsuz etkileyen unsurlar konusunda farklı görüşler ortaya koymuşlar, söz konusu sorunları çözmeye yönelik ise daha dar kapsamlı öneriler geliştirmişlerdir.
\end{abstract}

Anahtar Kelimeler: Yazma, yazma eğitimi, Türkçe öğretmenleri, yazma eğitiminde sorunlar, yazma eğitiminin sorunlarına yönelik çözüm önerileri.

\section{The Factors Affecting Teaching Writing Negatively and Suggested Solutions According to the Opinions of Turkish Teachers}

\begin{abstract}
The aim of the research is to determine the problems that Turkish teachers encounter in teaching writing, and their solutions for these problems. For this purpose, phenomenological pattern, one of the qualitative research methods, was used in the research. The participants of the research are 25 Turkish teachers working at the Ministry of National Education. A semi-structured interview form was used to determine the opinions of the participants. The findings were analysed through content analysis and presented in categories. According to the findings of the research, there are eight factors that negatively affect the process of teaching writing, and they are as follows "student; family, school and environment; textbook; lesson duration and curriculum; Ministry of National Education and education system; teacher; primary education of
\end{abstract}

\footnotetext{
* Bu çalışma, ikinci araştırmacının danışmanlığında birinci araştırmacı tarafından yürütülen "Türkçe Öğretmenlerinin Görüşlerine Göre Yazma Eğitimi Uygulamalarının Değerlendirilmesi” adlı yüksek lisans tezinin verilerinden yararlanılarak üretilmiştir.

** Yüksek Lisans Öğrencisi, Gazi Üniversitesi, Eğitim Bilimleri Enstitüsü, Türkçe Eğitimi Bilim Dalı, Eskişehir, hk03fb@gmail.com, ORCID: orcid.org/ 0000-0002-0988-600X

*** Prof. Dr., Gazi Üniversitesi, Gazi Eğitim Fakültesi, Türkçe ve Sosyal Bilimler Eğitimi Bölümü, Türkçe Eğitimi Ana Bilim Dalı, Ankara, ydogan@gazi.edu.tr, ORCID: orcid.org/ 0000-0001-8384-9808
} 
students; undergraduate education of teachers". The suggestions made by the teachers to improve their writing skills are gathered in nine different categories as follows "student; application, activity; family, school and environment; textbook; lesson duration and curriculum; Ministry of National Education and education system; teacher; primary education of students; undergraduate education". The interviewed teachers expressed different opinions on the factors that negatively affect teaching writing, and they developed limited suggestions for solving the aforementioned problems.

Keywords: writing, teaching writing, Turkish teachers, problems in teaching writing, solutions for the problems of teaching writing.

\section{Giriş}

İnsanoğlu doğduğu andan itibaren kendini ifade etme çabasına girer. Sosyal bir varlık olması sebebiyle hayatı boyunca başkalarıyla iletişim kurma ihtiyacı hisseder. Bu ihtiyaçtan dolayı sembol, resim ve sesle haberleşme gibi birçok iletişim aracı kullanılmıştır. Fakat bunların içinde dil, iletişimin en önemli aracı olarak yerini almıştır. Aksan'a (2020) göre "Dil, sözlü ve yazılı olarak iletişimde kullandığımız, doğduğumuzda hazır bularak edinmeye başladığımız, doğrudan doğruya insana özgü, çok güçlü, büyülü bir düzendir; düşünme ve düşünüleni aktarma dizgesidir" (s. 17). Insanların düşündüklerini, bulunduğu zamanın ötesine ve çevresine kolaylıkla iletmesini sağlaması dilin ne kadar güçlü ve büyülü bir iletişim aracı olduğunu ortaya koymaktadır. Dil; dinleme/izleme, konuşma, okuma ve yazma adı verilen dört temel dil becerisinden oluşur. İnsanın toplum içinde etkili iletişim kurması ve sosyal hayatını devam ettirmesi için dil becerilerini doğru ve etkili kullanması gerekir. Kişinin kendini yazılı olarak anlatmasını sağlayan yazma, bunların arasında en son edinilen dil becerisidir.

Kaynaklarda yazma çeşitli şekillerde tanımlanmıştır. Özbay'a (2016) göre "Yazma, duygu, düşünce, istek ve olayların belli kurallara uygun olarak birtakım sembollerle anlatılmasıdır" (s. 115). Güneş'e (2009) göre "Yazma, beyinde yapılandırılmış bilgilerin yazıya dökülmesi işlemidir" (s. 11). Akyol'a (2000) göre "Yazma düşüncelerimizi ifade edebilmek için gerekli sembol ve işaretleri kurallarına uygun bir şekilde ve okunaklı olarak üretebilmektir" (s. 37-48). Göçer'e (2015) göre "Yazma, bireylerin bir konudaki duygu, düşünce, hayal, izlenim veya yaşadıklarını dilin temel kurallarına uyarak ve belli bir planlama çerçevesinde anlatma becerisidir" (s. 199). Bu açıklamalardan hareketle yazma; kişinin duygu, düşünce, izlenim ve hayallerini belli kurallar çerçevesinde, düzenli olarak yazıyla anlatma becerisi olarak tanımlanabilir.

Yazma, bazı öğrenciler hatta öğretmenler tarafından bir yetenek işi olarak görülmektedir. Oysaki çoğu yazar araştırarak, okuyarak, bol bol yazarak, düzelterek, tekrar yazarak bir eseri ortaya koymakta ve yazar olmaktadır. Üstelik yazma çalışmalarında öğrencilerden bir yazar ustalığında deneme, makale, öykü veya masal yazmaları istenmemektedir. Öğrencilerden asıl istenen duygu, düşünce ve hayallerini bir düzen içerisinde yazılı olarak karşı tarafa aktarmalarıdır (Aşılıoğlu, 1993, s. 138) Bu nedenle de yazma yetenekten çok bir beceri işidir. Yazma becerisi, doğuştan edinilemez ancak yazma eğitimi sayesinde kazandırılır ve geliştirilir.

Yazma eğitimi; bireylerin duygu, düşünce ve hayallerini yazıyla doğru, düzenli ve anlamlı bir şekilde aktarması için çeşitli etkinlik ve geri bildirimlerle verilen eğitimdir. Günlük hayatta yazma becerisinin kullanımına bakıldığında yazma eğitiminin ne kadar önemli olduğu görülmektedir. Uzaktaki tanıdığımızın hatırını sormak, şikâyet ya da isteklerimizi bir kuruma iletmek, bir işin yapılışını tarif etmek, alışveriş listesi oluşturmak, günlük tutmak, unutmamak için not tutmak, hislerimizi sevdiklerimize iletmek ve düşüncelerimizi sosyal veya sanal ortamda paylaşmak vb. birçok alanda yazma becerisi kullanılır. Bunun yanında yazma kişisel, toplumsal ve uğraşsal bir ihtiyaç olarak görülür. İnsanlarla iletişim kurmayı sağladığı için kişisel, insanları bilgilendirdiği, onlara yön verdiği ve onları aydınlattığı için toplumsal, hangi meslekten olursak olalım yazmak zorunda olduğumuz için uğraşsal bir ihtiyaçtır (Arıcı ve Ungan, 2017, s. 4). Ayrıca yazma becerisi, bireyin eğitim hayatında akademik başarısı, iş hayatında da kariyerini geliştirmesi açısından gereklidir. Yazmanın hayatımızda bu denli yer aldığı düşünüldüğünde kendini düzensiz, gelişigüzel cümlelerle ifade eden bir kişinin günlük yaşamında birçok sorunla karşılaşması muhtemeldir. Bu nedenle yazma becerisine ve bu becerinin eğitimine gerekli önem verilmelidir. 
Yazma eğitimi, ortaokul düzeyinde Türkçe dersi kapsamında verilmektedir. Bu nedenle öğrencilerin yazma becerilerinin gelişiminden Türkçe öğretmenleri sorumludur. Bununla birlikte Türkçe öğretmenlerinin verdikleri yazma eğitimi sonucunda öğrencilerinin yazma becerilerinin yeterince gelişmediği görülmektedir. Yapılan araştırmalara göre sadece ortaokul değil, lise hatta üniversite öğrencilerinin yazma becerisi istenen düzeyin altındadır (Arıcı, 2008; Demir, 2013; Deniz, 2017; İlaslan, 2007). Öğrenciler genellikle planlama, yazım ve noktalama, ana fikir ve yardımcı fikir oluşturma ve doğru cümle kurmada yanlışa düşmektedirler (Arıcı, 2008; Arıcı ve Ungan, 2008). Yazılı anlatım, hem içerik hem de biçimsel olarak birçok kurala dikkat etmeyi ve birçok beceriyi bir arada kullanmayı gerektirdiği için öğrencilerin zorlandığı bir alandır. Bununla birlikte öğrenciler diğer dil becerilerine nazaran yazmaya karşı daha isteksizdirler (Elma ve Bütün, 2015, s.111). Öğrencilerin yazma becerilerini geliştirmeden ziyade onlara yazma eyleminin sevdirilememiş olması dikkat çekicidir.

Öğrencilerin yazma becerilerindeki bu başarısızlıklarının altında birçok neden yatmaktadır. Yapılan araştırmalara göre öğretmenler yazma çalışmaları sırasında bazı zorluklar yaşamaktadırlar. Bu zorluklar sınıf mevcudunun fazla olması, yazmaya ayrılan sürenin yetersiz olması, müfredatı yetiştirme kaygısı, öğrencilerin yazmaya karşı ilgisiz ve isteksiz olmaları, ilkokulda yeterli yazma eğitimi almamaları, az kitap okumaları, kelime hazinelerinin yetersiz olması, merkezî sınavların çoktan seçmeli sorularla yapılması, yazma etkinliklerinde iyi bir rehberlik yapılmaması gibi nedenlerden kaynaklanmaktadır (Bilgin, 2018; Güney, 2016; Solak, 2013). Tüm bunların dışında okul, cinsiyet, anne ve babanın aylık gelir düzeyi, ailenin aylık geliri, eve süreli yayın girmesi, köy veya kentte yaşama, Türkçe dersinden alınan not ve öğrencinin en çok sevdiği ders gibi etkenlerin de yazma başarısını etkilediği bilinmektedir (Çelik, 2012; Deniz, 2000; Kırbaş, 2006). Bu sorunların kaynaklarına bakıldığında öğrenci, çevre-aile ve eğitim sistemi başıkları öne çıkmaktadır. Bu başlıklar yazma becerisini etkileyen önemli unsurlardır. Fakat öğrencilerin yazma becerisinde en az bunlar kadar önemli olan bir diğer etmen de öğretmendir. Öğretmen, beceri kazandırma sürecinde, Türkçe Dersi Öğretim Programı́nı uygulayan, çeşitli etkinliklerle, verdiği dönütlerle ve yaptığı değerlendirmelerle öğrencinin yazma becerisini geliştirmeye çalışan ve ona yol gösteren, yazma eğitiminin ana bileşenidir. Öyle ki yukarıda sayılan olumsuzlukların etkisini en aza indirerek öğrencilerin yazma becerilerini geliştirebilecek temel unsur da yine öğretmendir. Bu nedenle öğrencilerin yazma becerisi için öğretmenin, izlediği yöntem ve stratejiler ve yaptığı uygulamalar oldukça önemlidir.

İnsanoğlunun hayatın çoğu alanında ihtiyaç duyduğu yazma becerisinin, ülkemizde öğrencilere yeterince kazandırılamadığı ve bunun altında birçok neden yattığı görülmektedir. Yazma eğitimini etkileyen bu olumsuzlukların tespiti ve çözülmesi için yazma eğitiminin ortaokul düzeyindeki uygulayıcısı olan Türkçe öğretmenlerinin görüşleri oldukça önem arz etmektedir. Bu bağlamda araştırmamızın amacı Türkçe öğretmenlerinin yazma eğitiminde karşılaştıkları sorunları ve bu sorunlara yönelik çözüm önerilerinin neler olduğunu tespit etmektedir. Bu amaç doğrultusunda aşağıdaki iki soruya cevap aranmıştır:

1. Türkçe öğretmenlerine göre yazma eğitimini olumsuz etkileyen unsurlar nelerdir?

2. Türkçe öğretmenlerine göre yazma becerisini geliştirebilmek için neler yapılabilir?

\section{Araştırmanın Modeli}

\section{Yöntem}

Araştırmada nitel araştırma yöntemi kullanılmıştır. Nitel araştırmalar, bilgileri ve deneyimleriyle gerçekliğin, bulunduğu bağlamda anlamlandırılmasını temel alan araştırmalardır (Büyüköztürk, Kılı̧̧ Çakmak, Akgün, Karadeniz ve Demirel, 2014, s. 12). Araştırmada nitel araştırma desenlerinden olgubilim (fenomenoloji) kullanılmıştır. Olgubilim farkında olduğumuz fakat derinlemesine ve ayrıntılı bir bilgiye sahip olmadığımız olgularla ilgilenir. Günlük hayatta olaylar, deneyimler, algılar, yönelimler, kavramlar ve durumlar gibi olgularla sıkça karşılaşılır. Bize tümüyle yabancı olmayan, aynı zamanda da tam anlamını kavrayamadığımız bu tür olguların detaylı bir şekilde araştırılıp ortaya koyulmasında olgubilim deseni kullanılmaktadır. Olgubilim araştırmalarında veri kaynaklarını, araştırılan olguyu yaşayan ve bu olguyu dışa vurabilecek bireyler ya da gruplar oluşturmaktadır. Olgubilim deseninin başlıca veri toplama aracı ise görüşmedir (Yıldırım ve Şimşek, 
2018, s. 69-71). Bu çalışmada da Türkçe öğretmenlerinin görüşleri alınarak yazma eğitimini olumsuz etkileyen unsurlar ve çözüm önerileri belirlendiği için olgubilim deseni tercih edilmiştir.

\section{Çalışma Grubu}

Araştırmanın çalışma grubunu ortaokullarda görev yapan 25 Türkçe öğretmeni oluşturmaktadır. Çalışma grubu, amaçlı örnekleme yöntemleri içinden "kolay ulaşılabilir durum örneklemesi" ile belirlenmiştir. Kolay ulaşılabilir durum örneklemesi, araştırmacıya yakın ve ulaşılması kolay olan bir durumun seçildiği, araştırmaya hız ve pratiklik kazandıran bir örnekleme çeşididir (Yıldırım ve Şimşek, 2018, s. 123). Araştırmanın güvenirlik ve geçerliğini artırmak için örneklem seçilirken çeşitleme stratejisinden yararlanılmıştır. Bu kapsamda farklı cinsiyet, yaş ve hizmet süresinde olan, farklı şehir ve yerleşim yerinde (il / ilçe / kırsal kesim) görev yapan öğretmenler seçilerek veri kaynağı çeşitlemesi sağlanmıştır. Öğretmenler, görüşme sırasına göre 1 'den $25^{\prime}$ e kadar "Ö1, Ö2, Ö3..." şeklinde kodlanmıştır. Veri kaynağı olan Türkçe öğretmenlerinin özellikleri aşağıdaki tabloda ele alınmıştır.

Tablo 1.

Öğretmenlerin Cinsiyet ve Yaşlarına iliş̧kin Bilgiler

\begin{tabular}{lccc}
\hline Durum & Kategori & Frekans & $\%$ \\
\hline Cinsiyet & Kadın & 13 & 52 \\
& Erkek & 12 & 48 \\
\hline Yaş & $\leq 25$ & 2 & 8 \\
& $26-30$ & 5 & 20 \\
& $31-35$ & 11 & 44 \\
& $36-40$ & 7 & 28 \\
\hline
\end{tabular}

Tablo 1'de araştırmaya katılan öğretmenlerin cinsiyet ve yaş dağılımları verilmiştir. Araştırmaya 13 kadın, 12 erkek olmak üzere toplam 25 öğretmen katılmıştır. Böylece öğretmenler arasında cinsiyet dengesi sağlanmaya çalışılmıştır. Öğretmenlerin yaş dağılımlarına bakıldığında ise \%44 ile en fazla 31-35 yaş aralığında öğretmenin araştırmaya katıldığı görülmektedir. Bunu \%28 ile 36-40, \%20 ile $26-30$ ve \%8 ile 25 ve altı yaş aralığındaki öğretmenler izlemektedir.

Aşağıda araştırmaya katılan öğretmenlerin mesleki deneyim ve girmiş oldukları haftalık Türkçe ders saatlerinin dağııımını gösteren tabloya yer verilmiştir.

Tablo 2.

Öğretmenlerin Mesleki Deneyim ve Haftalık Ders Saatlerine ilişkin Bilgiler

\begin{tabular}{llcl}
\hline Durum & Kategori & Frekans & $\%$ \\
\hline Mesleki Deneyim & $0-5$ Yıl & 3 & 12 \\
& $6-10$ YII & 11 & 44 \\
& $11+$ Yıl & 11 & 44 \\
\hline Haftalık Ders Saati & $\leq 15$ Saat & 6 & 24 \\
& $16-20$ Saat & 3 & 12 \\
& $21-25$ Saat & 9 & 36 \\
& $26+$ Saat & 7 & 28 \\
\hline
\end{tabular}

Tablo 2'de araştırmaya katılan öğretmenlerin mesleki deneyim ve girmiş oldukları haftalık Türkçe ders saatlerine ilişkin bilgilere yer verilmiştir. Buna göre \%44 oranla en fazla 6-10 yıl ile 11 ve üzeri yıl mesleki deneyime sahip öğretmen araştırmaya katılmıştır. Meslek hayatının ilk yıllarında olan 0-5 yıllık mesleki deneyime sahip öğretmen oranı ise \%12 olarak tespit edilmiştir. Araştırmanın çalışma grubunda, deneyimli ve çok deneyimli öğretmenlerin yanında güncel akademik bilgilere sahip, göreve yeni başlamış öğretmenlerin de bulunduğu görülmektedir.

Tablo 2 incelendiğinde öğretmenlerin girmiş oldukları haftalık Türkçe ders saatleri farklılık göstermektedir. Buna göre \%36 oranla en fazla öğretmen 21-25 saat derse girmektedir. 
Öğretmenlerin \%28'i 26 ve daha fazla saat derse girerken \%24'ü 15 ve daha az saat, \%12'si ise 16-20 saat derse girmektedir. verilmiştir.

Aşağıda öğretmenlerin görev yaptıkları şehir ve yerleşim yerini belirten tabloya yer

Tablo 3.

Öğretmenlerin Görev Yaptıkları Şehir ve Yerleşim Yerine Iliş̧kin Bilgiler

\begin{tabular}{llcc}
\hline Durum & Kategori & Frekans & $\%$ \\
\hline Görev Yapılan Şehir & Eskişehir & 16 & 64 \\
& Konya & 5 & 20 \\
& Muş & 2 & 8 \\
& Şanlıurfa & 2 & 8 \\
\hline Görev Yapılan Yerleşim & II & 18 & 72 \\
Yeri & İlçe & 4 & 16 \\
& Kırsal Kesim & 3 & 12 \\
\hline
\end{tabular}

Tablo 3'te araştırmaya katılan öğretmenlerin görev yaptıkları şehir ve yerleşim yerine ilişkin bilgilere yer verilmiştir. Buna göre öğretmenlerin \%64'ü Eskişehir, \%20'si Konya, \%8'i Muş ve \%8'i Şanlıurfa ilinde görev yapmaktadır. Ayrıca öğretmenlerin görev yaptıkları ilçeler: Eskişehir'de merkez Tepebaşı, Konya'da Çumra ve merkez Selçuklu, Muş'ta Bulanık, Şanlıurfa'da ise Akçakale ve merkez Eyyübiye ilçeleridir.

Tablo 3 incelendiğinde öğretmenlerin görev yaptıkları yerleşim yerlerinin de farklı olduğu görülmektedir. Buna göre öğretmenlerin $\% 72$ 'si il merkezinde, \%16'sı ilçe merkezinde ve \%12'si kırsal kesimde görev yapmaktadır.

\section{Veri Toplama Araçları}

Araştırmada verilerin toplanması için yarı yapılandırılmış görüşme formu kullanılmıştır. Yarı yapılandırılmış görüşme, sorulmak istenen soruların önceden hazırlandığı ancak sürecin gelişimine göre farklı yan veya alt sorularla görüşmenin akışının etkilenebildiği bir görüşme tekniğidir. Yarı yapılandırılmış görüşme, kişinin yanıtlarını açmasına ve ayrıntılandırmasına imkân sağlar. Bu teknikte kişi görüşme sırasında bazı soruları başka soruların içinde yanıtlamışsa tekrar o soru sorulmayabilir. Yarı yapılandırılmış görüşme belirli düzeyde standartlığa sahip olması ve araştırmaya esneklik sağlaması nedeniyle eğitimbilim araştırmaları için daha uygun olduğu görünümünü vermektedir (Türnüklü, 2000, s. 547).

\section{Verilerin Toplanması}

Araştırma kapsamında Türkçe öğretmenlerinin yazma eğitimi hakkındaki uygulama, görüş ve önerilerini belirlemek için araştırmacılar tarafından yarı yapılandırılmış görüşme formu taslağı hazırlanmıştır. Formda yer alan görüşme sorularının geçerlik ve uygunluğunu artırmak için 3 alan uzmanından uzman görüşü alınmıştır. Bu görüşler doğrultusunda görüşme formunda gerekli düzeltmeler yapılmıştır. Ardından soruların geçerlik, güvenirlik ve uygunluğunu belirlemek için 3 farklı Türkçe öğretmeniyle pilot görüşme yapılmıştır. Bu görüşsmeler sonucunda yarı yapılandırılmış görüşme formuna son hâli verilmiştir.

Görüşme formunu öğretmenlere uygulamadan önce Gazi Üniversitesi Etik Komisyonu'na başvurulmuş ve gerekli etik izni alınmıştır. Etik izninden sonra Gazi Üniversitesi Eğitim Bilimleri Enstitüsü aracılığıyla MEB'e öğretmenlerle araştırma yapma izni için başvurulmuş ve gerekli izin alınmıştır. Alınan izin aracılı̆ıyla yirmi öğretmenle okullarına gidilerek yüz yüze görüşme gerçekleştirilmiştir. Çeşitli nedenlerden dolayı yüz yüze görüşme imkânı olmayan beş öğretmenle ise uzaktan iletişim araçlarıyla görüşme yapılmıştır. Yüz yüze görüşsmeler; öğretmenler odası, müdür odası veya boş sınıf gibi uygun ortamlarda, öğretmenlerin uygun zamanlarında gerçekleştirilmiştir. Görüşme öncesinde öğretmenlere araştırma konusu ve görüşme soruları hakkında gerekli bilgiler verilmiştir. Görüşme sırasında, belirlenen sorular öğretmenlere yöneltilmiş, öğretmenlerin verdikleri 
cevaplara ve görüşmenin akışına göre ek sorular da sorulmuştur. Genellikle 30-60 dakika arasında gerçekleşen görüşmeler öğretmenin izni dâhilinde ses kaydına alınmıştır. Sonrasında kaydedilen görüşmeler, araştırmacı tarafından bilgisayar ortamında yazıya aktarılmıştır.

\section{Verilerin Analizi}

Araştırmada elde edilen verilerin çözümünde içerik analizi yöntemi kullanılmıştır. Büyüköztürk vd.ne (2014) göre "içerik analizi, belirli kurallara dayalı kodlamalarla bir metnin bazı sözcüklerinin daha küçük içerik kategorileri ile özetlendiği sistematik, yinelenebilir bir teknik olarak tanımlanır. Bir mesajın belli özelliklerinin objektif ve sistematik bir şekilde tanınmasına yönelik çıkarımların yapıldığı bir tekniktir" (s. 246).

Yazıya geçirilen görüşmeler analiz edilirken birinci araştırmacı tarafından öncelikle birkaç defa okunmuş ve ardından kodlama işlemi gerçekleştirilmiştir. Kodlama, veriler arasında yer alan anlamlı bölümlerin (bir sözcük, cümle, paragraf gibi) isimlendirilme sürecidir (Yıldırım ve Şimşek, 2018, s. 242). Araştırmada öğretmenlerin görüşlerinin daha açık ve anlaşıır bir biçimde okuyucuya sunulması amacıyla cümleler şeklinde kodlama yöntemine başvurulmuştur. Cümle yapısına uygun olmayan bazı veriler ise sözcük ve söz grubu şeklinde kodlanmıştır. Verilerin kodlanmasının ardından birbiriyle ilişkili kodlar kategorileştirilmiştir. Kategori (tema), birbiriyle ilişkili olan kavramların daha üst düzey bir temada sınıflandırımasıdır (Yıldırım ve Şimşek, 2018, s. 242).

Kodlara ve kategorilere ayrılan veriler, bulgular kısmında tablolaştırılmıştır. Kodlanan ve kategorileştirilen veriler, frekans ve yüzde şeklinde gösterilmiştir.

Kodlaması yapılan veriler tablo hâlinde sunulduktan sonra her tablonun altına açıklaması ve yorumlaması yapılmıştır. Bu sırada öğretmenlerin görüşlerinden alıntılar yapılarak yorumlar desteklenmiştir. Ayrıntılı betimleme, ham verinin ortaya çıkan kavram ve temalara göre yeniden düzenlenmiş bir biçimde yorum katılmadan okuyucuya aktarılmasıdır. Doğrudan alıntılar birer ayrıntılı betimleme örneğidir (Yıldırım ve Şimşek, 2018, s. 282). Böylece geçerliği artırma stratejileri arasından ayrıntılı betimlemeden faydalanılmıştır.

\section{Geçerlik ve Güvenirlik}

Veri analizi sırasında yapılan kodlamaların geçerlik ve güvenirliğini sağlamak amacıyla 2 farklı alan uzmanına kodlama yaptırılmıştır. Kodlamalar arası uyumun $\% 80$ ve üzerinde olması, kodlamaların güvenilir olduğunu göstermektedir (Miles ve Huberman 1994 ve Patton 2002'den aktaran Baltacı, 2017, s. 8). Miles ve Huberman'ın kodlama güvenirlik formülüyle kodlayıcılar arası uyum $\% 97,13$ olarak hesaplanmıştır. Bu sonuçtan hareketle verilerin geçerli ve güvenilir olduğu söylenebilir.

\section{Bulgular}

Bu bölümde araştırmaya katılan öğretmenlerden elde edilen bulgulara ve bu bulgularla ilgili yorumlara yer verilmiştir. Bulgular belirlenen kategori ve kodlar aracilı̆ıyla tablolar hâlinde sunulmuştur. Her tablonun altına öğretmen görüşlerinden alıntılar yapılarak yorumlanmıştır.

\section{Alt Probleme ilişkin Bulgular}

Aşağıda "Türkçe öğretmenlerine göre yazma eğitimini olumsuz etkileyen unsurlar nelerdir?" alt problemine ilişkin öğretmen görüşleri ele alınmıştır.

Tablo 4.

Yazma Eğitimini Olumsuz Etkileyen Unsurlar

\begin{tabular}{llcc}
\hline Kategori & Kod & Frekans & $\%$ \\
\hline Öğrenci & Yeterince kitap okumamaları & 12 & 48 \\
& Kelime hazinelerinin gelişmemiş olması & 7 & 28 \\
& Yazmaya karşı isteksiz olmaları & 5 & 20 \\
& Sınav odaklı düşünüp yazma becerisine önem vermemeleri & 4 & 16 \\
& Türkçeyi zengin ve doğru kullanmamaları & 3 & 12
\end{tabular}


Türkçe Öğretmenlerinin Görüşlerine Göre Yazma Eğitimini Olumsuz Etkileyen Unsurlar ve Çözüm Önerileri

\begin{tabular}{|c|c|c|c|}
\hline & Yazmaktan sıkılmaları & 3 & 12 \\
\hline & Yazmayı sevmemeleri & 3 & 12 \\
\hline & Yazma becerilerine karşı özgüvenlerinin eksik olması & 2 & 8 \\
\hline & Ana dillerinin farklı olması & 2 & 8 \\
\hline & Birbirlerinin yazdıklarıyla dalga geçmeleri & 2 & 8 \\
\hline & Bilgi birikiminin çok az olması & 2 & 8 \\
\hline & Soyut düşüncelerinin yeterince gelişmemiş olması & 1 & 4 \\
\hline & Bilgisayar oyunlarına düşkün olmaları & 1 & 4 \\
\hline & Yazarlığa gereken önemi vermemeleri & 1 & 4 \\
\hline & Kolaya kaçmaları & 1 & 4 \\
\hline & Dikkatlerinin çabuk dağılması & 1 & 4 \\
\hline & Yazılarının kötü olması ve bunu geliştirmeye çalışmamaları & 1 & 4 \\
\hline & Nitelikli kitap okumamaları & 1 & 4 \\
\hline & Yöresel ağızla konuşmaları & 1 & 4 \\
\hline \multirow[t]{19}{*}{ Aile, Okul ve Çevre } & Ailenin yazma becerisinin öneminin farkında olmaması & 8 & 32 \\
\hline & Teknoloji, internet ve sosyal medyanın olumsuz etkileri & 8 & 32 \\
\hline & Ailenin çocukla yeterince ilgilenmemesi & 5 & 20 \\
\hline & Toplum olarak kitap okuma alışkanlığımızın olmaması & 3 & 12 \\
\hline & Ailenin sosyoekonomik durumu & 2 & 8 \\
\hline & Sınıf mevcudunun çok olması & 2 & 8 \\
\hline & Ailenin ve çevrenin de dili zengin kullanmaması & 1 & 4 \\
\hline & Klavye ve ekran yazarlığının yaygınlaşması & 1 & 4 \\
\hline & Günümüzde çocuğa örnek kaliteli yazarların çıkmaması & 1 & 4 \\
\hline & Toplum olarak yazma alışkanlığımızın olmaması & 1 & 4 \\
\hline & $\begin{array}{l}\text { Çocuğun çevresinde örnek alabileceği yazı yazan birinin } \\
\text { olmaması }\end{array}$ & 1 & 4 \\
\hline & $\begin{array}{l}\text { Çocuğun okulunda ve çevresinde kütüphane ve kitap } \\
\text { bulunmaması }\end{array}$ & 1 & 4 \\
\hline & Ailenin kitap okumayı önemsiz görmesi & 1 & 4 \\
\hline & Seçmeli derslerin müdürün inisiyatifinde seçilmesi & 1 & 4 \\
\hline & Ülkemizde kitap fiyatlarının fazla olması & 1 & 4 \\
\hline & $\begin{array}{l}\text { Kütüphanelerdeki kitapların çocukların dikkatini çekecek, } \\
\text { güncel ve yeni nesil kitaplar olmaması }\end{array}$ & 1 & 4 \\
\hline & Çocukların mevsimlik işçi olarak çalıştırılması & 1 & 4 \\
\hline & $\begin{array}{l}\text { Tüm okulların yeterli teknik destek ve donanıma sahip } \\
\text { olmaması }\end{array}$ & 1 & 4 \\
\hline & Ailenin eğitim düzeyinin düşük olması & 1 & 4 \\
\hline \multirow[t]{7}{*}{ Ders Kitabı } & Ders kitabının öğrencilerin seviyesine uygun olmaması & 11 & 44 \\
\hline & Ders kitabı ve yazma etkinliklerinin tekdüze ve sıkıcı olması & 8 & 32 \\
\hline & $\begin{array}{l}\text { Yazma etkinliklerinin öğrencilerin beceri ve yaratıcılıklarını } \\
\text { sınırlandırıcı olması }\end{array}$ & 2 & 8 \\
\hline & Ders kitabında çok fazla metin ve etkinliklerin olması & 2 & 8 \\
\hline & $\begin{array}{l}\text { Ders kitaplarının, metinlerin ve etkinliklerin yeni sınav } \\
\text { sistemine uygun olmaması }\end{array}$ & 1 & 4 \\
\hline & Yazma etkinliklerinin hep en sona konması & 1 & 4 \\
\hline & Ders kitabının baskı ve görsellerinin kalitesiz olması & 1 & 4 \\
\hline Ders Saati ve & Ders saatlerinin yazma becerisi için yetersiz olması & 8 & 32 \\
\hline \multirow[t]{3}{*}{ Müfredat } & Müfredat, hedef ve kazanımların çok fazla olması & 5 & 20 \\
\hline & Türkçe müfredatına sözel mantık sorularının eklenmesi & 2 & 8 \\
\hline & Müfredatta dil bilgisi konularının yoğun olması & 1 & 4 \\
\hline MEB ve Eğitim & LGS'de açık uçlu yazma becerisi sorusu sorulmaması & 15 & 60 \\
\hline \multirow[t]{4}{*}{ Sistemi } & Test yöntemine dayalı bir sınav ve eğitim sistemimizin olması & 9 & 36 \\
\hline & Bir dönem bitişik eğik yazının zorunlu tutulması & 3 & 12 \\
\hline & $\begin{array}{l}\text { Yazmaya yetenekli öğrencilerin yönlendirileceği bir alanın } \\
\text { olmaması }\end{array}$ & 1 & 4 \\
\hline & $\begin{array}{l}\text { MEB tarafından yapılan ikinci yazılıların test olması ve } \\
\text { doğrudan yazma becerisi sorusu sorulmaması }\end{array}$ & 1 & 4 \\
\hline
\end{tabular}




\begin{tabular}{|c|c|c|c|}
\hline & $\begin{array}{l}\text { Öğrencinin okuduğu kitabı anlamasından çok kaç sayfa kitap } \\
\text { okuduğuna önem verilmesi }\end{array}$ & 1 & 4 \\
\hline & $\begin{array}{l}\text { Eğitim sisteminin beceri geliştirmeye öğretimden daha az } \\
\text { önem vermesi }\end{array}$ & 1 & 4 \\
\hline & $\begin{array}{l}\text { Öğrencinin dil becerilerini ayrı ayrı değerlendirebileceğimiz bir } \\
\text { sistemin olmaması }\end{array}$ & 1 & 4 \\
\hline & LGS'deki Türkçe sorularının kapsam geçerliliğinin düşük olması & 1 & 4 \\
\hline & İkinci yazılıların test yapılması & 1 & 4 \\
\hline & $\begin{array}{l}\text { Ülkenin her yerinde aynı eğitim programlarının uygulanması, } \\
\text { programların esnek olmaması }\end{array}$ & 1 & 4 \\
\hline & Sınıfta kalmanın olmaması & 1 & 4 \\
\hline & Öğretmenlere verilen hizmet içi eğitimlerin yetersiz olması & 1 & 4 \\
\hline \multirow[t]{13}{*}{ Öğretmen } & Türkçe eğitimini dil bilgisinden ibaret görmeleri & 3 & 12 \\
\hline & Görevlerini tam anlamıyla yapmamaları & 2 & 8 \\
\hline & Kendilerini geliştirmemeleri & 2 & 8 \\
\hline & Kitap okuma alışkanlıklarının olmaması & 2 & 8 \\
\hline & Sadece test ve sınava odaklı olmaları & 2 & 8 \\
\hline & Türkçenin düzgün kullanımına özen göstermemeleri & 2 & 8 \\
\hline & Eleştirilerini yapıcı bir şekilde yapmamaları & 1 & 4 \\
\hline & Genel kültürlerinin zayıf olması & 1 & 4 \\
\hline & $\begin{array}{l}\text { Seçmeli Yazarlık ve Yazma Becerileri Dersi'ne gereken önemi } \\
\text { vermemeleri }\end{array}$ & 1 & 4 \\
\hline & $\begin{array}{l}\text { Okulda Türkçe öğretmenlerinin üstüne çok sorumluluk } \\
\text { yüklenmesi }\end{array}$ & 1 & 4 \\
\hline & $\begin{array}{l}\text { Diğer branş öğretmenlerinin Türkçeye ve yazma becerisine } \\
\text { yeterince önem vermemeleri }\end{array}$ & 1 & 4 \\
\hline & Öğrencileri yazmaya karşı güdüleyememeleri & 1 & 4 \\
\hline & Nitelikli yazı yazamamaları & 1 & 4 \\
\hline \multirow{4}{*}{$\begin{array}{l}\text { Öğrencilerin Illkokul } \\
\text { Eğitimi }\end{array}$} & Öğrencilere ilkokulda yazmanın yeterince öğretilememesi & 7 & 28 \\
\hline & $\begin{array}{l}\text { İlkokulda yazma becerisinden çok test çözme becerisine önem } \\
\text { verilmesi }\end{array}$ & 4 & 16 \\
\hline & $\begin{array}{l}\text { İlkokul öğretmenlerinin öğrencilerin yazılarına yeterince geri } \\
\text { bildirim vermemesi }\end{array}$ & 1 & 4 \\
\hline & illkokulda öğrencilere okuma alışkanlığı kazandııılamaması & 1 & 4 \\
\hline Öğretmenlerin & Yazma eğitimi uygulamalarının yetersiz olması & 10 & 40 \\
\hline \multirow[t]{5}{*}{ Lisans Eğitimi } & Öğretmenlik uygulamalarının yetersiz olması & 5 & 20 \\
\hline & $\begin{array}{l}\text { Yazma eğitimiyle ilgili yeterli bilgisi ve okul deneyimi olmayan } \\
\text { öğretmenlerin yazma eğitimi dersi vermesi }\end{array}$ & 4 & 16 \\
\hline & $\begin{array}{l}\text { Öğretmenlik hayatında işe yaramayacak üst düzey bir lisans } \\
\text { müfredatının olması }\end{array}$ & 2 & 8 \\
\hline & $\begin{array}{l}\text { Düşük seviyedeki öğrencilere nasıl eğitim verileceğinin } \\
\text { öğretilmemesi }\end{array}$ & 1 & 4 \\
\hline & $\begin{array}{l}\text { Ana dili farklı olan öğrencilere nasıl eğitim verileceğinin } \\
\text { öğretilmemesi }\end{array}$ & 1 & 4 \\
\hline
\end{tabular}

Öğrencilerin İlkokul Eğitimi

Tablo 4'te Türkçe öğretmenlerine göre yazma eğitimini olumsuz etkileyen unsurlar yer almaktadır. Bu unsurlar "öğrenci; aile, okul ve çevre; ders kitabı, ders saati ve müfredat, MEB ve eğitim sistemi; öğretmen; öğrencilerin ilkokul eğitimi; öğretmenlerin lisans eğitimi" kategorileri altında detaylı şekilde sunulmuştur. Tüm kategoriler incelendiğinde öğretmenlerin \%60'ı LGS'de açık uçlu yazma becerisi sorusu sorulmamasını, $\% 48$ 'i öğrencilerin yeterince kitap okumamalarını, $\% 44$ 'ü ders kitabının öğrencilerin seviyesine uygun olmamasını, \%40'ı öğretmenlerin lisans eğitimindeki yazma eğitimi uygulamalarının yetersiz olmasını ve $\% 36$ sı test yöntemine dayalı bir sınav ve eğitim sistemimizin olmasını yazma eğitimini olumsuz etkileyen bir unsur olarak değerlendirmiştir.

Öğrenci kategorisine bakıldığında yazma eğitimini olumsuz etkileyen unsurların başında öğrencilerin yeterince kitap okumamaları gelmektedir. Sonra sırasıyla öğrencilerin kelime 
hazinelerinin düşük olması, yazmaya karşı isteksiz olmaları, sınav odaklı düşünüp yazma becerisine önem vermemeleri gibi yazma becerisini olumsuz etkileyen etkenler öğretmenler tarafından en çok dile getirilen hususlar olmuştur.

Öğretmenlerin neredeyse yarısı (\%48) öğrencilerin yeterince kitap okumamalarını yazma becerisi için olumsuz bir etken olarak görmektedir. Bu öğretmenlerden Ö15, "Çocukların az kitap okuması en başta bence. Okumuyor çocuklar, okumadıkları için neyi, nasıl yazacaklarını bilmiyorlar bence. En büyük sorun bu." diyerek öğrencilerin yazma becerisini etkileyen unsurların başında kitap okumamalarının geldiğini söylemiştir.

Öğrencilerin kelime hazinelerinin gelişmemiş olması yazma becerisini olumsuz etkileyen unsurların ikinci sırasında (\%28) gelmektedir. Kitap okumak öğrencinin yeni kelimelerle karşılaşmasını sağlar. Bu nedenle kitap okumayla kelime hazinesinin gelişmesi doğrudan ilişkilidir. Ö23 bu konuda, "Okumadıkları için sözcük dağarcığı yok, sözcük dağarcığı olmadığı için de anlatamıyor. Zaten Türkçenin amacı dört temel beceridir. Zaten dört temel beceriden okuma ve dinlemeyi yapamazlarsa diğerlerini de yapamıyorlar." sözleriyle öğrencilerin kelime hazinelerinin zayıf olmasının kitap okumamalarına dayandığını, bunun sonucunda da anlatımlarının zayıfladığını belirtmiştir.

Öğrencilerin yazmaya karşı isteksiz olmaları öğretmenlerin beşte biri tarafından dile getirilen bir olumsuzluktur. Bu öğretmenlerden Ö18, "Yazmaya karşı yeterli istek, motivasyon olmaması çok olumsuz bir etken en başta. Burada tabii ki bizim de eksiklerimiz var muhakkak. Çocuğa bunu en başından beri sevdirememiş olmak bir olumsuzluk." diyerek öğrencinin yazmaya karşı isteksiz olmasını yazmaya karşı en başta gelen olumsuz bir etken olarak görmektedir.

Bazı öğretmenler (\%16), öğrencilerin sınav odaklı düşünüp yazma becerisine gereken önemi vermediklerini belirtmişlerdir. Ö14 bu durumu, "Sekizinci sınıflar yapmak istemiyorlar. Onlar için bu bir vakit kaybı. Bunun eve ödev olmasını istiyorlar. Onda da cuma günü gibi günlerin olmasını istiyorlar ki hafta sonu olsun işte hocam biz daha rahat yapabilelim. İşte hafta içi yetiştirmemiz gereken sorularımız oluyor ancak hafta sonu vakit ayırabiliyoruz. Onların da gözünde çok önemli olan bir dal değil yazma." diyerek açıklamıştır.

Aile, okul ve çevre kategorisine bakıldığında yazma becerisini olumsuz etkileyen unsurların başında ailenin yazma becerisinin öneminin farkında olmaması ve teknoloji, internet ve sosyal medya gelmektedir. Öğretmenlerin yaklaşık üçte birinin (\%32) olumsuzluk olarak dile getirdiği ailenin yazma becerisinin öneminin farkında olmaması unsuru hakkında Ö14, "Veli açısından değerlendirecek olursak veli için yazma eğitimi ya da yazma ile ilgili harcadığımız zaman aslında boşa geçmiş bir zaman. Veli bunu bu şekilde görüyor. Çünkü hocam bu test sınavına girecek, konuları belli, diyor. İste bunu veliye anlatamıyoruz. Yazamayan, kendisini ifade etmeyi öğrenmemiş bir öğrenci zaten okuduğunu anlayamayacak, dediğimizde veli açısından çok havada kalıyor." şeklinde düşüncelerini belirtmiştir.

Aynı kategoride yine öğretmenlerin yaklaşık üçte birinin (\%32) olumsuz unsur olarak gördüğü teknoloji, internet ve sosyal medya hakkında Ö19, "Yazma eğitimini olumsuz etkileyen en önemli unsur bir kere sosyal medya, dış unsurlar olarak baktığınızda. Yani çocuğun kelime kullanma becerisini inanılmaz derecede fazla etkiliyor, özellikle bu sosyal medyada kullandıkları kelimeler. Kelimelerin yazılışını orada farklı gördükleri için 'nbr, slm' bunları gördükleri için çocuk yazı yazarken de bazen bu harfleri bile atlayabiliyor. Bir kere yazım hatası burada meydana gelebiliyor." demiştir.

Öğretmenlerin yazma eğitimi için olumsuzluk olarak gördükleri bir başka durum velilerin çocuklarıyla yeterince ilgilenmemeleridir. Öğretmenlerin beşte birinin olumsuzluk olarak gördüğü bu konuda Ö15, "Bizim velilerimiz çok ilgisiz, alakasız veliler oldukları için onlarla ilgili olumsuzluklar tabii ki var. Velilerimiz yok ki, mesela toplantı yapıyoruz iki veli geliyor. Onlar da durumu nasıl, notu nasıl, bitti gitti. Sormuyorlar çocuğum yazabiliyor mu? Çocuğuma yazdırın veya yazdırmayın diye hiç böyle bir dönüt almadım diyebilirim." diyerek görüşlerini bildirmiştir.

Ders kitabı kategorisi çerçevesinde yazma eğitimini olumsuz etkileyen unsurlara bakıldığında en çok (\%44) ders kitabının öğrencilerin seviyesine uygun olmamasının öğretmenler tarafından belirtildiği görülmüştür. Bu olumsuzluk hakkında Ö19, "Ders kitabı açısından olumsuzluk var. Şöyle var, bazı etkinlikler yazma becerilerine çok uyumlu değil bazı sınıflar için. Yani öğrenciden beklenemeyecek derecede etkinlikler verilmiş. Mesela altılarda o konu yok ama o konuyla ilgili yazı 
yazmasını istiyorlar. Ya da uyumlu olmayan parçalar veriliyor. Bu parçaya yönelik yazı yazması isteniyor. Sıkıntılar burada var." ve Ö6, "Ders kitaplarındaki etkinlikler biraz ütopik kalıyor çocuklara, somut değil, ayakları yere basmıyor. Çocuklar sürekli bir anlama çabasına giriyor. Bu ne anlatıyor, şu ne diye?" sözleriyle ders kitabı ve etkinliklerin öğrenci seviyesinin üstünde kaldığını ve anlaşılmadığını ifade etmiştir.

Öğrencileri yazmaya güdülemesi ve motive etmesi için ders kitabı ve yazma etkinliklerinin ilgi çekici, istek uyandırıcı ve farklı farklı olması gerekmektedir. Fakat öğretmenlerin yaklaşık üçte biri (\%32) ders kitabı ve yazma etkinliklerinin tekdüze ve sıkıcı olduğundan bahsetmiştir. Bu konuda öğretmenlerden Ö21 düşüncelerini "Yazma becerisi açısından sürekli kendini tekrar eden etkinlikler var. Çocukların bir yerden sonra şikâyetleri başlıyor. Bunu iki metin önce yapmıştık, bir metin önce yapmıştık şeklinde. Sürekli aynı tarzda özellikle de altıncı sınıfta sürekli tekrar eden etkinlikler var yazmada. Bir de yazma deyince hep böyle bir konu hakkında yazma var. Hiç duyu hakkında yazma yok mesela. Hep bir söz, bir konu hakkında şiir yazma, anı yazma... Çocukların artık sürekli tekrara düşüp sıkıldığı etkinlikler var. Daha renkli olabilir, daha eğlenceli olabilir." şeklinde ifade etmiştir.

Ders saati ve müfredat kategorisine bakıldığında, öğretmenlerin en çok ders saatlerinin yazma becerisi için yetersiz olmasının (\%32) daha sonra ise müfredat, hedef ve kazanımların çok fazla olmasının (\%20) yazma becerisini olumsuz etkilediğini düşündükleri görülmektedir. Ortaokul düzeyinde Türkçe ders saati 5 ve 6 . sınıflarda altı saat, 7 ve 8 . sınıflarda ise beş saattir. Yazma becerisi için bu ders saatlerinin yetersiz olduğunu düşünen öğretmenlerden Ö14, "Süre. Kesinlikle süre. Yani yoğun bir müfredatta süre çok büyük bir sıkıntı yaratıyor yazma eğitiminde. Onun dışında çok büyük bir problem olduğunu düşünmüyorum ama süre büyük bir sıkıntı." diyerek süreyi yazmayı etkileyen en büyük unsur olarak gördüğünü dile getirmiştir.

Ders saatinden sonra öğretmenlerin en çok şikâyet ettikleri konu müfredat, hedef ve kazanımların çok fazla olmasıdır. Öğretmenlerin beşte birinin görüş belirttiği bu konuda Ö21, "Kazanımlar fazla ve ders saatlerinde yetişmiyor. Genelde destekleme ve yetiştirme kurslarında da konu işlendiği zamanlar oluyor. Konu yetişmediği zamanlar oluyor." diyerek kazanımların fazla olması nedeniyle Türkçe ders saatinde bu kazanımların hepsinin kazandırılmasının mümkün olmadığını dile getirmiştir.

MEB ve eğitim sistemi kategorisinde öğretmenler tarafından $L G S^{\prime}$ de açık uçlu yazma becerisi sorusu sorulmaması yazma eğitimini en fazla olumsuz etkileyen unsur olarak görülmektedir. Öğretmenlerin yarıdan fazlasının (\%60) yazma eğitimi açısından olumsuz gördüğü bu konuda Ö18'in, "...Tabii olumsuz etkiliyor. Diyorum ya artık çıkarcı bir anlayış var. Bakıyor bana somut olarak bir faydası var mı bunun? Hayır, yok, gibi düşünüyor bunu. Mesela bana şey diyen öğrenciler oldu: 'Öğretmenim siz yazılıda otuz puan, yirmi beş puan buradan soruyorsunuz ama bu LGS'de çıkmıyor, Millî Eğitim yazılıda sormuyor.' Bunlar zaten ne oluyor, yazmaya karşı olumsuz bir algı oluşturuyor." sözleriyle ifade ettiği gibi öğrenciler LGS'de kendilerine puan getirisi olmadığını düşündükleri için yazma eğitimini önemsememekte ve yazmak istememektedirler. Bu durum öğretmenlere göre yazma eğitimini oldukça olumsuz etkilemektedir.

MEB ve eğitim sistemi kategorisinde öğretmenlerin ikinci en büyük olumsuzluk olarak gördükleri unsur test yöntemine dayalı bir sınav ve eğitim sisteminin olmasıdır. Öğretmenlerin \%36'sının yazma eğitimi için olumsuzluk olarak gördüğü bu konuda Ö12, "Eğitim sistemimiz tamamen test çözmeye yönelik. Çocuk test çözüyorsa tamam, gerisi önemli değil. Konuşması olmasa da olabilir, yazması olmasa da olabilir, dinlemesi olmasa da olabilir. Ama yeter ki çocuk testleri doğru cevaplasın. Böyle bir mantıkla yetiştiriyoruz çocukları. Bu mantığın bize çok büyük zararları var." sözleriyle teste dayalı eğitim sistemi nedeniyle öğrencinin temel dil becerilerine gereken önemin verilmediğini dile getirmiştir.

Öğretmen kategorisi çerçevesinde yazma eğitimini olumsuz etkileyen unsurlara bakıldı̆̆ında öğretmenlerin topluca üzerinde durdukları bir unsurun olmadığı göze çarpmaktadır. Bu kategoride en fazla olarak üç öğretmenin (\%12) yazma eğitimi açısından olumsuz olarak gördüğü bazı öğretmenlerin Türkçe eğitimini dil bilgisinden ibaret görmeleri unsuru yer almaktadır. Bu konuda Ö24, "Öğretmenliği sadece dil bilgisi anlatmak olarak gören arkadaşlar var. Öğrencinin aslında temel gereksiniminin ufkunun genişlemesi olması gerektiğini bilmeyen, öyle temel, metodik bilgilerle oradan mezun 
olduğunda donanımlı öğrenci olduğunu zanneden arkadaşlar çoğunlukta maalesef." diyerek bazı öğretmenlerin dört temel beceriden çok dil bilgisine önem verdiğini ve öğrencinin ufkunu açacak bir eğitim yapmadıklarını ifade etmiştir.

Öğrencilerin ilkokul eğitimi kategorisinde öğretmenler en çok (\%28) öğrencilere ilkokulda yazmanın yeterince öğretilememesini yazma eğitimini olumsuz etkileyen bir unsur olarak değerlendirmektedirler. Ö10 bu konuda "Başlangıçta ilköğretimde bizim istediğimiz bir şey var, ortaokula gelen çocuğun genellikle yazı karakterlerini bilmesini istiyoruz. Yazı karakterlerini bilmediği zaman çocuk bazı harfler büyük, bazıları küçük şekilde çok saçma bir yazı sistemi geliştirip yanımıza geliyor. Onu düzeltmeye çalışırken yazma işleminin asıl temalarına giremiyoruz. En büyük sorun burada. Eğer sınıf öğretmenimiz yazma kurallarını ve harfleri düzgün öğretmişse biz ondan sonraki temaları ögrretmekte hiç güçlük çekmiyoruz. Çocuklar zaten bir şeyler ortaya çıkarmak için elinden gelenleri yapıyor. Çocukların genel yapısı biliyorsam yaparım şeklinde. Ama bilmiyorsa orada bir sorun ortaya çıkıyor." diyerek öğrencilerin ilkokulda edinmeleri gereken beceriler üzerinde durdukları için ortaokul kazanımlarını öğrenciye veremediklerini bu nedenle de öğrencilerin yazma becerilerinin olumsuz etkilendiğini ifade etmiştir. Ayrıca öğretmene göre bu durum yazmayı olumsuz etkileyen en büyük sorundur.

Öğretmenlerin \%16'sı ilkokulda yazma becerisinden çok test çözmeye önem verilmesinin yazma eğitimini olumsuz etkilediğini düşünmektedir. Bu görüşteki öğretmenlerden Ö17, "ilkokulda ögrretmenler daha çok test ağırlıklı eğitim veriyor. Ortaokula geldiği zaman beşinci sınıfta bu çocuk doğru düzgün bir cümle bile kuramıyor. Bu yüzden yazmak istemiyorlar, ön yargılılar. O yüzden çocukların tutumlarını da etkiliyor." sözleriyle ilkokulda test ağılıklı bir eğitim verilmesi nedeniyle öğrencilerin kendilerini yazılı olarak ifade edemediklerini, bu durumun öğrencilerin yazmaya karşı isteksiz ve ön yargılı olmalarına yol açtığını ifade etmiştir.

Öğretmenlerin lisans eğitimi kategorisine bakıldığında öğretmenlerin yarıya yakınının (\%40) lisans eğitiminde yazma eğitimi uygulamalarının yetersiz olduğunu düşündüğü görülmektedir. Bu konuda Ö21, "Diğer bir şey yazma eğitimi dersinde öğrenciye neler yapacağımıza yönelik bilgiler verilmemesi lisansta. Daha çok teorik bilgilerde kalması. Ben mesela bir öğrencinin yazma düzeyini belirleme araçlarını çok etkin öğrendiğimizi hatırlamıyorum. Bir öğrencinin yazma düzeyini belirledikten sonra bir hedef belirleyip o öğrenciyi hangi düzeye çıkarabileceğimize dair bir bilgi de hatırlamıyorum." diyerek üniversitedeki yazma eğitiminin uygulamadan çok teoriye dayandığını bu nedenle meslek hayatında yazma eğitimi verirken zorlandığını ifade etmiştir.

Öğretmen yetiştiren fakültelerin son sınıfında Öğretmenlik Uygulaması dersi verilmektedir. Bu ders kapsamında lisans öğrencisi okul ortamına giderek gözlem yapar ve ders anlatır. Kısaca mesleği yerinde görerek, yaparak, yaşayarak tecrübe eder. Tablodan anlaşılacağı gibi öğretmenlerin beşte biri lisans eğitimindeki öğretmenlik uygulamalarının yetersiz olduğunu düşünmektedir. Bu öğretmenlerden Ö17, "Üniversite ve okul arasında daha fazla iş birliği yapılabilir. Üniversite hocaları kitaplardan öğrendikleri şeyleri öğrencilere anlatıyorlar. Öğrenciler bize stajyer olarak geldikleri zaman o kitaplardan ögrrendikleri şeyleri yapmaya çalışıorlar ama uygulamaya dönüşsmüyor. Yani teoride kalıyor, pratiğe dönmüyor." diyerek lisanstaki öğretmenlik uygulamalarının teoride kaldığını, uygulamaya dönük bir içerikten yoksun olduğunu belirtmiştir. Ö15 ise "Çok eksik. Çok eksik bir ögrretmenim ben şu an. Üniversitede nasıl öğretmen olunur, nasıl öğretilir, nasıl yazdırılır bunun eğitimini kesinlikle tam anlamıyla aldığıma inanmıyorum." sözleriyle lisans eğitimi sırasında öğretmenliği tam anlamıyla öğrenemediği için kendini yetersiz gördüğünü dile getirmiştir.

Öğretmenlerin \%16'sı yazma eğitimiyle ilgili yeterli bilgisi ve okul deneyimi olmayan öğretmenlerin yazma eğitimi dersi vermesinin yazmayı olumsuz etkilediğini düşünmektedir. Ö22, "Üniversitelerdeki hocaların eğitimiyle ilgili aslında bu. Onlar biraz fildişi kulelerinde yaşadıkları için kendileri çok sahaya inemiyorlar. Özellikle daha böyle yaş almış hocalarımız edebiyat açısından bakıyor. Hoca eski edebiyat hocası bu şekilde hikâye, deneme yazma seviyesine inemiyor yani. Üst düzey kalıyorlar. Hocalar edebiyatçı, o alanda bilgisi yok. Ama şu an Türkçe eğitimi bölümünde bir şeyler yaptırmaya çalışıyor." diyerek lisans eğitimindeki öğretmenlerin ortaokul öğrenci profilini birebir görmedikleri yani sahaya inmedikleri için bu seviyede bir yazma eğitimi dersi veremediklerini dile getirmiştir. 


\section{Alt Probleme ilişkin Bulgular}

Aşağıda "Türkçe öğretmenlerine göre yazma becerisini geliştirebilmek için neler yapılabilir?" alt problemine ilişkin öğretmen görüşlerine yer verilmiştir.

Tablo 5.

Yazma Becerisini Geliştirmek Için Öneriler

\begin{tabular}{|c|c|c|c|}
\hline Kategori & Kod & Frekans & $\%$ \\
\hline Öğrenci & Öğrenciler daha fazla kitap okuyabilirler. & 1 & 4 \\
\hline \multirow{19}{*}{ Uygulama, Etkinlik } & Öğrencileri güdüleyici, ödüllü yazma yarışmaları yapılabilir. & 7 & 28 \\
\hline & $\begin{array}{l}\text { Tecrübelerini paylaşmaları için yazar ve şairler okullara davet } \\
\text { edilebilir. }\end{array}$ & 4 & 16 \\
\hline & Gezi ve doğa yürüyüşü sonrasında yazma çalışması yapılabilir. & 4 & 16 \\
\hline & $\begin{array}{l}\text { Okulda bir yazar ekibi oluşturulup okul dergisi veya gazetesi } \\
\text { çıarılabilir. }\end{array}$ & 2 & 8 \\
\hline & Okullar arasında mektup arkadaşlığı yapılabilir. & 2 & 8 \\
\hline & Yazma eğitimi derslerini özel eğitimli öğretmenler verebilir. & 2 & 8 \\
\hline & Metin tamamlama etkinlikleri yapılabilir. & 1 & 4 \\
\hline & Akrostiş çalışmaları yapılabilir. & 1 & 4 \\
\hline & $\begin{array}{l}\text { Yazmaya yetenekli ve istekli öğrencileri için daha fazla egzersiz } \\
\text { açılabilir. }\end{array}$ & 1 & 4 \\
\hline & Öğrencilere nitelikli çocuk edebiyatı eserleri okutulabilir. & 1 & 4 \\
\hline & $\begin{array}{l}\text { Çocuklarla bol bol konuşulup onların kendilerini ifade } \\
\text { etmelerine imkân sağlanabilir. }\end{array}$ & 1 & 4 \\
\hline & Yazma etkinliklerinde ödüllendirme yapılabilir. & 1 & 4 \\
\hline & $\begin{array}{l}\text { Kitabı olmayan çocuklara kitap temin edilip öğrencilerin } \\
\text { okumaları teşvik edilebilir. }\end{array}$ & 1 & 4 \\
\hline & Kütüphane kullanımı yaygınlaştırılabilir. & 1 & 4 \\
\hline & $\begin{array}{l}\text { Videoyu yarıda kesip gerisini tamamlama etkinlikleri } \\
\text { yapılabilir. }\end{array}$ & 1 & 4 \\
\hline & Elektronik yazma uygulamaları yaptırılabilir. & 1 & 4 \\
\hline & $\begin{array}{l}\text { Sekizinci sınıflar hariç diğer sınıfların tüm Türkçe sınavları yazılı } \\
\text { olabilir. }\end{array}$ & 1 & 4 \\
\hline & Okuduğu kitabı değerlendirme yazıları yazdırılabilir. & 1 & 4 \\
\hline & $\begin{array}{l}\text { Öğrencilerin yaratıcılıklarını açığa çıkarabilecekleri yazma } \\
\text { etkinlikleri artırılabilir. }\end{array}$ & 1 & 4 \\
\hline \multirow[t]{5}{*}{ Aile, Okul ve Çevre } & Okul ve aile etkileşimi güçlendirilebilir. & 2 & 8 \\
\hline & Aile çocuğuyla daha fazla ilgilenebilir. & 1 & 4 \\
\hline & Aile, kitap okuyarak öğrenciye örnek olabilir. & 1 & 4 \\
\hline & Aile, öğretmenin öğretim faaliyetlerine müdahale etmemelidir. & 1 & 4 \\
\hline & $\begin{array}{l}\text { Toplum olarak yazmaya bakış açımızı değiştirip yazmanın } \\
\text { önemini anlayabiliriz. }\end{array}$ & 1 & 4 \\
\hline \multirow[t]{7}{*}{ Ders Kitabı } & $\begin{array}{l}\text { Ders kitabı, birbirini tekrar etmeyen, ilgi çekici etkinliklerle } \\
\text { geliştirilebilir. }\end{array}$ & 6 & 24 \\
\hline & $\begin{array}{l}\text { Öğrencilerin seviyesine daha uygun metin ve etkinliklere yer } \\
\text { verilebilir. }\end{array}$ & 5 & 20 \\
\hline & $\begin{array}{l}\text { Öğretmenlerin derste kullanabilecekleri örnek yazma eğitimi } \\
\text { etkinlik kitabı hazırlanabilir. }\end{array}$ & 2 & 8 \\
\hline & Kitaplara konu anlatım bölümleri de eklenebilir. & 1 & 4 \\
\hline & Ders kitabına kaliteli çocuk edebiyatı metinleri konulabilir. & 1 & 4 \\
\hline & Ders kitabında yazma etkinlikleri hep en sona konmayabilir. & 1 & 4 \\
\hline & Ders kitabında daha az metne yer verilebilir. & 1 & 4 \\
\hline Ders Saati ve & Türkçe ders saatleri artırılabilir. & 5 & 20 \\
\hline Müfredat & Türkçe Dersi Öğretim Programı’ndaki kazanımlar azaltılabilir. & 2 & 8 \\
\hline MEB ve Eğitim & LGS'de açık uçlu yazma becerisi sorusu sorulabilir. & 6 & 24 \\
\hline \multirow[t]{2}{*}{ Sistemi } & Yazma becerisi için ayrı ve zorunlu bir ders konulabilir. & 6 & 24 \\
\hline & Yazma becerisiyle ilgili bir yazma atölyesi oluşturulabilir. & 2 & 8 \\
\hline
\end{tabular}


Seçmeli Yazarlık ve Yazma Becerileri Dersi'ni seçmede

1

öğrenciler teşvik edilebilir.

Sınava dayalı eğitim sistemi değiştirilip beceriye dayalı bir

eğitim sistemi geliştirebilir.

Okul öncesinden itibaren her sınıfa zorunlu okuma dersi

konulabilir.

MEB öğrencilerin yazılarını toplayıp aylık bir dergi veya gazete

çıkarabilir.

İlkokul ve ortaokul süreci bilgi öğretmekten çok dört temel

beceriyi geliştirme odaklı planlanabilir.

Yazılılarda yazma becerisine daha fazla yer ayrılabilir ve açık

uçlu sorular daha çok sorulabilir.

MEB, yalnızca yazma becerisi için ayrı bir kitap çıkarabilir.

Okul dergisi veya gazetesi çıkarmak için maddi destek

sağlanabilir.

Seçmeli Yazarlık ve Yazma Becerileri Dersi için bir kitap

hazırlanabilir.

İmkânı olmayan okullara akıllı tahta, projeksiyon, bilgisayar

gibi teknik destekler sağlanabilir.

Öğrenci, dört temel dil becerisi ayrı ayrı olarak bir gelişim

dosyası ile tüm eğitim hayatı boyunca izlenebilir.

Dil bilgisi ve dört temel dil becerisi ayrı ayrı derslere ayrılıp ayrı

ayrı değerlendirilebilir.

LGS kaldırılıp öğrenciler ağırlıklı not ortalamalarıyla bir üst

kademeye yerleştirilebilir.

\begin{tabular}{|c|c|c|c|}
\hline \multirow[t]{4}{*}{ Öğretmen } & $\begin{array}{l}\text { Yazma becerisi konusunda çeşitli kurslarla öğretmenler } \\
\text { eğitilebilir. }\end{array}$ & 2 & 8 \\
\hline & $\begin{array}{l}\text { Diğer branş öğretmenleri de yazma becerisine daha çok önem } \\
\text { verebilirler. }\end{array}$ & 2 & 8 \\
\hline & $\begin{array}{l}\text { Öğretmenler, öğrencilere ilkokuldan itibaren daha fazla kitap } \\
\text { okutup daha fazla yazdırabilirler. }\end{array}$ & 1 & 4 \\
\hline & Öğretmenler sürekli kendilerini geliştirebilirler. & 1 & 4 \\
\hline \multirow[t]{2}{*}{$\begin{array}{l}\text { Öğrencilerin İlkokul } \\
\text { Eğitimi }\end{array}$} & $\begin{array}{l}\text { İlkokuldan itibaren öğrencilerin yazma becerilerine daha fazla } \\
\text { önem verilebilir. }\end{array}$ & 2 & 8 \\
\hline & $\begin{array}{l}\text { Öğrencinin ilk önce zekâ türünü ve yeteneklerini belirleyip ona } \\
\text { göre eğitim verebiliriz. }\end{array}$ & 1 & 4 \\
\hline Öğretmenlerin & Yazma eğitimi derslerinde daha fazla uygulama yapılabilir. & 9 & 36 \\
\hline \multirow[t]{10}{*}{ Lisans Eğitimi } & $\begin{array}{l}\text { Öğretmenlik uygulamaları derslerinin niteliği ve sayısı } \\
\text { artırılabilir. }\end{array}$ & 4 & 16 \\
\hline & Yazma becerisinde uzman öğretmenler ders vermelidir. & 3 & 12 \\
\hline & $\begin{array}{l}\text { Lisansta ortaokul sınıf ortamını bilen öğretmenler ders } \\
\text { vermelidir. }\end{array}$ & 2 & 8 \\
\hline & $\begin{array}{l}\text { Lisans sonrasında da lisans öğretmenleriyle Türkçe } \\
\text { öğretmenlerinin iletişim kurabileceği bir kanal oluşturulabilir. }\end{array}$ & 2 & 8 \\
\hline & Yazma becerisi dersleri artırılabilir. & 2 & 8 \\
\hline & Üniversite ile okulların etkileşimi artırılabilir. & 1 & 4 \\
\hline & $\begin{array}{l}\text { Lisans müfredatı ile öğretmenin okulda öğretecekleri } \\
\text { arasındaki uyum artırılabilir. }\end{array}$ & 1 & 4 \\
\hline & $\begin{array}{l}\text { Öğretmen adaylarının ülkenin farklı bölgelerindeki okullarda } \\
\text { da öğretmenlik uygulaması yapmaları sağlanabilir. }\end{array}$ & 1 & 4 \\
\hline & Mikro öğretim yöntemi uygulanabilir. & 1 & 4 \\
\hline & $\begin{array}{l}\text { Öğretmenlik mülakatı öğretmen adayı eğitim fakültesine } \\
\text { girmeden yapılabilir. }\end{array}$ & 1 & 4 \\
\hline
\end{tabular}

Tablo 5'te "öğrenci; uygulama, etkinlik; aile, okul ve çevre; ders kitabı; ders saati ve müfredat; MEB ve eğitim sistemi; öğretmen; öğrencilerin ilkokul eğitimi; öğretmenlerin lisans eğitimi" 
kategorileri çerçevesinde öğretmenlerin, öğrencilerin yazma becerilerini geliştirmeye yönelik önerilerine yer verilmiştir.

Öğrenci kategorisinde bir öğretmen tarafından öğrencilere yönelik tek bir öneri sunulmuştur. "Öğrenciler daha fazla kitap okuyabilirler." şeklindeki öneri hakkında Ö19, "Kitap okumalarını artırmaları gerekiyor. Günümüzde EBA var, EBA'da elektronik kitaplar var, onları kullanabilirler." şeklinde görüş belirtmiştir.

Uygulama, etkinlik kategorisi incelendiğinde öğrencilerin yazma becerilerini geliştirmek için öğretmenlerin yaklaşık üçte birinin (\%28) "Öğrencileri güdüleyici, ödüllü yazma yarışmaları yapılabilir." önerisini sundukları görülmektedir. Bu öğretmenlerden Ö19 "Yazma becerileri ile ilgili yarışmalar daha sıklıkla düzenlenebilir, bunlara yönelik uygulamalar yapılabilir ve bu yarışmalar şevklendirici, ödüllendirici olmalı. Bunları uyguladıkları zaman hem öğrencilerin katılımları artacaktır, hem istekleri artacaktır." diyerek ödüllendirici yazma yarışmalarının öğrenciyi yazmaya isteklendirdiğini, bu nedenle de öğrencilerin yazma becerilerini geliştirdiğini ifade etmiştir.

Öğretmenlerden dördü "Tecrübelerini paylaşmaları için yazar ve şairler okullara davet edilebilir." önerisini dile getirmişlerdir. Ö8, "Yazarlar okullara yönlendirilebilir. Nasıl yazdılar, nasıl başladılar, kendi hikâyelerini kendi dillerinden anlatmaları etkiler diye düşünüyorum yazma becerilerini." diyerek yazarların tecrübelerini paylaşmalarının öğrencilere yazma konusunda örnek olabileceğini belirtmiştir.

Öğretmenlerden dördü öğrencilerin yazma becerilerini geliştirebilmek için "Gezi veya doğa yürüyüşü sonrasında yazma çalışması yapılabilir." önerisinde bulunmuşlardır. Ö25, "Gördüklerimizle, mesela gezdiğimiz yerlerle yaşantımız çeşitlenebilir. Bunun sonucunda da yazıya aktararak bir ürün ortaya konabilir. Mesela her sene okul bir gezi düzenleyebilir. Bu, öğrencilerin bakış açılarını da değiştirir, hem yeni yerler de tanımıs olurlar. Insanlarla tanışmış olur, yeni yerler keşfetmiş olur. Bu da ister istemez yazdığı şeylere etki edecektir. Böyle bir şey zorunlu tutulabilir." diyerek geziler sayesinde öğrencilerin yaşantıları ve anlatacaklarının artmasıyla yazılarının ve yazma becerilerinin gelişebileceğini dile getirmiştir.

Aile, okul ve çevre kategorisinde az sayıda öğretmen, öğrencilerin yazma becerilerini geliştirmek için beş farklı öneride bulunmuştur. Bunlardan en fazla olarak iki öğretmenin dile getirdiği "Okul ve aile etkileşimi güçlendirilebilir." önerisi olmuştur. Bu konuda Ö17, "Işs velilere de düşüyor. Veliler çocuklarıyla iletişim, etkileşim içerisinde oldukları zaman, daha fazla kitap okudukları zaman veya çocuğuna zaman ayırdığı zaman daha iyi olacaktır. Velilerle etkili iletişim veli, okul, öğrenci iletişimi olması gerekiyor." şeklinde görüşünü belirtmiştir.

Ders kitabı kategorisi incelendiğinde öğretmenlerin \%24 oranla en çok "Ders kitabı, birbirini tekrar etmeyen, ilgi çekici etkinliklerle geliştirilebilir." önerisini sundukları görülmektedir. Bu öğretmenlerden Ö2 bu durumu, "Ders kitabı bence çok sıkıcı. Sürekli bir konu verip 'Hadi bununla ilgili yazı yazın.' diyor. Onun yerine bir karikatür vererek öğrenciye neler anladığını yazdırabilir. Karikatür tamamlamaya yer verilebilir. Daha farklı olarak bir bulmaca verip cevaplarından hareketle bir metin yazdırabilir." sözleriyle özetlemiştir.

Öğretmenlerin beşte biri öğrencilerin yazma becerilerini geliştirebilmek için "Öğrencilerin seviyesine daha uygun metin ve etkinliklere yer verilebilir." önerisinde bulunmuşlardır. Bu konuda Ö5, "Etkinliklerin ve metinlerin çocuğun düzeyinde olması gerekiyor. Çünkü arada kalıyoruz biz bazen. Bir metin koyuyorsun mesela 'Fare ile Tavşan' beşinci sınıf metni. Sonra bir metin koyuyorsun, çocuklara anlatıyorsun anlamıyor, anlatıyorsun anlamıyor. Yani bu dengeyi yakalamamız gerekiyor. Metinlerin çocukların bilişsel düzeylerine uygun olması gerekiyor. Etkinliklerin de öyle çocuğa daha çok hitap edecek şekilde olması gerekiyor." diyerek metinlerin ve etkinliklerin öğrencilerin bilişsel seviyelerine uygun ve öğrencilerin yapabileceği türde olması gerektiğini dile getirmiştir.

iki öğretmen, öğrencilerin yazma becerilerini geliştirebilmek için "Öğretmenlerin derste kullanabilecekleri örnek yazma eğitimi etkinlik kitabı hazırlanabilir." şeklinde bir öneride bulunmuşlardır. Ö12, "Belki öğretmenler için de örnek etkinlikler tasarlanabilir, bu şekilde yardımcı olunabilir. Burada öğretmen arkadaşların kullandığı ve faydalı olduğu etkinlikler varsa o etkinliklerin bir kitapçık hâline getirilmesi veya bir sitede yayımlanması olabilir." diyerek öğretmenlerin faydalı bulduğu yazma etkinliklerinin yazılı ya da dijital olarak paylaşılabileceğini dile getirmiştir. 
Ders saati ve müfredat kategorisinde öğrencilerin yazma becerilerini geliştirebilmek için öğretmenlerin \%20'si en fazla "Türkçe ders saatleri artırılabilir." önerisinde bulunmuşlardır. Bu konuda Ö4, "Ne yazık ki en büyük sıkıntıyı zaten ders saatinde yaşıyoruz. Altı saate çıkarıldı beş ve altıncı sınıflarda, yedi ve sekizlerde beş saat. Bir sınıfta yirmi kişi olduğunu düşünürsek ancak iki üç dakika düşüyor ders başına. O yüzden yazma becerisinde öğretmenler genellikle ev ödevi şeklinde değerlendiriyorlar ama bir saatini mutlaka sınıf ortamında işlemeye ya da yapmaya çalışıyoruz. Belki güzel okuma- yazma gibi vb. derslerle daha teşvik edilebilir daha da artırılabilir." diyerek ders saatinin az olmasından dolayı öğretmenlerin öğrencilerin yazma becerileriyle yeterince ilgilenemediklerini dile getirmiştir.

İki öğretmen, öğrencilerin yazma becerilerini geliştirmek için "Türkçe Öğretim Programı́ndaki kazanımlar azaltılabilir." önerisinde bulunmuşlardır. Ö21, "Kazanımlar fazla ve ders saatlerinde yetişmiyor. Genelde destekleme ve yetiştirme kurslarında da konu işlendiği zamanlar oluyor. Konu yetişmediği zamanlar oluyor. Bu yüzden kesinlikle kazanımlar azaltılmalı." diyerek kazanımların fazla olması nedeniyle konular yetişmediği için kazanımların azaltılması gerektiğini söylemiştir.

MEB ve eğitim sistemi kategorisi incelendiğinde öğretmenlerin en fazla iki öneride bulunduğu görülmektedir. Bunlardan öğretmenlerin en fazla dile getirdiği öneri (\%24) "LGS'de açık uçlu yazma becerisi sorusu sorulabilir." olmuştur. Bu konuda Ö3, "LGS soruları açık uçlu sorular olabilir. Yazma becerisi olabilir. Çünkü bize yazma, konuşma, dinleme, okuma becerisi ve dil bilgisi veriyor. Ama sadece neyi ölçüyor? Dil bilgisini ölçüyor, okumayı ölçüyor ama dinleme, konuşma ve yazma yok. Ama bizim öğrencilerimiz de dinlediğini anlamıyor, dinlediğine yönelik sorulara cevap veremiyor. Biz hep bir tarafından ölçüyoruz öğrencileri bu da bir eksiklik." diyerek LGS'de öğrencilerin yazma, dinleme ve konuşma becerilerinin ölçülmemesinin onların bu becerilerde eksik kalmalarına yol açtığını dile getirmiştir.

Öğretmenlerin MEB ve eğitim sistemi kategorisinde en fazla (\%24) söz ettikleri diğer öneri ise "Yazma becerisi için ayrı ve zorunlu bir ders konulabilir." olmuştur. Bu öneriyi sunan öğretmenlerden Ö14, "işte bu Yazarlık ve Yazma Becerileri Dersi'ni seçmeli ders olmaktan çıkarabiliriz örneğin. $O$ zaman muhakkak hem Türkçe öğretmeninin Türkçe dersinde yazarlığa ayırması gereken zaman ortadan kalkar, böylece dersimizi çok rahat işleriz. Hem de yazarlığı ayrı mecburi bir ders olduğu için daha faydalı, daha işlevsel hâle getirebiliriz." sözleriyle Yazarlık ve Yazma Becerileri dersi zorunlu hâle getirildiğinde hem Türkçe dersinin daha rahat hem de bu dersin daha verimli işleneceğini öne sürmüştür.

Öğretmen kategorisi çerçevesinde araştırmaya katılan öğretmenler dört farklı öneride bulunmuşlardır. Bu önerilerden en fazla öğretmenin dile getirdiği iki farklı öneri vardır. Bunlardan ilki iki öğretmen tarafından dile getirilen "Yazma becerisi konusunda çeşitli kurslarla öğretmenler eğitilebilir." önerisidir. Ö13 bu konuda "Mesela öğretmenlere, Türkçe öğretmenlerine ve sınıf öğretmenlerine bununla ilgili bir hizmet içi eğitim verilebilir. Farklı teknikler anlatılabilir. Ben 2004'te girdim üniversiteye. Bizim girdiğimizle 2008'den sonra girenlerin aldığı eğitim farklı. Yani öğretmenler ister istemez kendilerini yenilemek zorunda. Onun için bence yazma becerisini geliştirmeyle alakalı bir şeyin yapılması lazım. Yeni sistemler gelmiş, yeni teknikler gelmiş bunlar verilebilir." diyerek her geçen yıl yazma eğitimi hakkında yeni teknik ve bilgilerin geliştiğini bunlardan haberdar olması için Türkçe ve sınıf öğretmenlerine hizmet içi eğitim kursları verilebileceğini belirtmiştir.

Öğretmen kategorisinde iki öğretmen tarafından dile getirilen bir diğer öneri ise "Diğer branş öğretmenleri de yazma becerisine daha çok önem verebilirler." olmuştur. Bu konuda Ö22, "Yazma konusunda tüm öğretmenlerin ortak olarak aynı şekilde yaklaşımının sağlanması, yani çocuğun kendini yazılı ifade etmede diğer öğretmenlerin de yazılısında sade test değil de çocuğun yazarak ifade edebileceği bir sorusunun olması gerekiyor en azından." şeklinde düşüncelerini ifade etmiştir.

Öğrencilerin ilkokul eğitimi kategorisinde öğretmenler iki farklı öneride bulunmuşlardır. Bunlardan en fazla öğretmen tarafından dile getirilen öneri "illkokuldan itibaren öğrencilerin yazma becerilerine daha fazla önem verilebilir." olmuştur. İki öğretmenin söz ettiği bu öneri hakkında Ö24, "Birinci sınıftan itibaren çok güzel bir yazma eğitimi verilebilir aslında. Yazma eğitimini birinci sınıfta hatta ana sınıfında verebilirsiniz. Çocuk kalem tutamaz belki ama çocuğun düşünce dünyasını genişletmeye yönelik etkinlikler yapabilirsiniz. Hayal ettirerek çocukları mesela. Böylece yazma 
eğitimi, eğitimin her kademesine yayılabilir." diyerek öğrencilere ilkokuldan hatta okul öncesinden itibaren onların düşünce dünyalarını, hayal etme becerilerini geliştiren daha iyi bir yazma eğitimi verilebileceğini söylemiştir.

Öğretmenlerin lisans eğitimi kategorisinde "Yazma eğitimi derslerinde daha fazla uygulama yapılabilir." önerisi öğrencilerin yazma becerilerini geliştirebilmek adına en fazla öğretmen tarafından dile getirilen öneri olmuştur. Öğretmenlerin üçte birinden fazlası (\%36) tarafından dile getirilen bu öneri bağlamında Ö25, "Daha fazla uygulamalı etkinlikler yapılabilir. Bizim yaratıcılığımızı geliştirmekten ziyade öğrencilere nasıl daha fazla fayda sağlayabiliriz, bu açıdan etkinlikler, uygulamalar yapılabilir ve ögrretilebilir. Teorik bilgi değil daha çok uygulama yaptırılabilir." sözleriyle teorik bilgiden daha çok uygulamaya dayalı bir yazma eğitimi dersinin verilmesini önermiştir.

Araştırmaya katılan öğretmenler, öğretmenlerin lisans eğitimi kategorisinde ikinci en fazla (\%16) olarak "Öğretmenlik uygulamaları derslerinin niteliği ve sayısı artırılabilir." önerisinde bulunmuşlardır. Ö23, bu konuda "Lisansta bildiğiniz gibi dördüncü sınıfta bir uygulama yapılıyor. Daha fazla yapılabilir. Mesela hemşirelikte insanlar ikinci sınıftan itibaren staja alınıyor. Biz de alınabiliriz yani. Daha çok öğrenciyle haşır neşir olup yetişiriz. Öğretmenliğin yüzde sekseni, doksanı kendini öğrenciye sevdirip kendini doğru düzgün ifade edebilmektir bence. Onun için ikinci sınıftan itibaren öğretmenler de staja alınabilir." sözleriyle önerisini açıklamıştır.

Öğretmenlerin lisans eğitimi kategorisi çerçevesinde bazı öğretmenler (\%12) "Yazma becerisinde uzman öğretmenler ders vermelidir." önerisinde bulunmuşlardır. Ö22, bu öneriyi "Hocanın ne yapacağını bilmesi önemli bence. Yazma eğitimine alanı yazma olan hoca girmesi gerekiyor." şeklinde dile getirmiştir.

\section{Sonuç ve Tartışma}

Türkçe öğretmenlerinin görüşleri çerçevesinde yazma eğitimi sürecini olumsuz etkileyen unsurların ve çözüm önerilerinin tespit edilmeye çalışıldığı bu çalışmada sorunların "öğrenci; aile, okul ve çevre; ders kitabı; ders saati ve müfredat; $M E B$ ve eğitim sistemi; öğretmen; öğrencilerin ilkokul eğitimi; öğretmenlerin lisans eğitimi" olmak üzere sekiz ana nedenden kaynaklandığı görülmektedir.

Türkçe öğretmenlerinin \%48'i öğrenciden kaynaklı yazma eğitimini olumsuz etkileyen unsurların başında öğrencilerin yeterince kitap okumamaları unsurunu görmektedir. Bunu sırasıyla öğrencilerin kelime hazinelerinin gelişmemiş olması (\%28), yazmaya karşı isteksiz olmaları (\%20) ve sınav odaklı düşünüp yazma becerisine önem vermemeleri (\%16) izlemektedir. Tağa ve Ünlü’nün (2013) yaptığı araştırmada öğretmenlerin, yazma eğitiminde karşılaşılan öğrenci kaynaklı sorunların başında öğrencilerin okuma alışkanlıklarının olmamasını gördüğü saptanmıştır. Bu durumu sırasıyla öğrencilerin yazma alışkanlıklarının olmaması, yazmaya karşı isteksizlikleri ve kelime hazinelerinin yetersiz olması sorunları izlemektedir. Bilgin (2018) öğretmenler ile anket ve gözleme dayalı yaptığı araştırmada öğrencilerin okuma alışkanlıklarının olmaması ve yazmaya karşı ilgisiz olmalarının yazma çalışmalarının verimsiz geçmesine neden olduğu sonucuna ulaşmıştır. Bahsi geçen çalışmalar ile mevcut çalışmanın sonuçları birbirini destekler niteliktedir.

Türkçe öğretmenlerinin görüşleri doğrultusunda aile, okul ve çevreden kaynaklı yazma eğitimini olumsuz etkileyen unsurlar olarak ailenin yazma becerisinin öneminin farkında olmaması (\%32), teknoloji, internet ve sosyal medyanın olumsuz etkileri (\%32), ailenin çocukla yeterince ilgilenmemesi (\%20) tespit edilmiştir. Alanyazında ailenin öğrencinin yazma becerisi üzerinde etkili olduğunu destekleyen çeşitli çalışmalar mevcuttur. Elma ve Bütün'ün (2015) öğretmen görüşlerine dayalı yapılandırdıkları araştırmada öğrencilerin bulundukları sosyal çevrenin yazılı anlatım becerilerinde etkili olduğu, kırsal veya düşük sosyo-ekonomik çevrede yetişen çocukların yazı yazacak bilgi dağarcığı ve tecrübeye ulaşmada zorluk yaşadıkları sonucuna ulaşıımıştır. Bununla birlikte araştırma neticesinde öğretmenlerin, öğrencilerin yazılı anlatım çalışmalarında zorlanmalarında velilerin eğitimsiz ve ilgisiz olmalarının da etkili olduğunu belirttikleri görülmüştür. Güven'in (2011) araştırmasında Türkçe Dersi Öğretim Programı'nın etkili bir şekilde uygulanmasında velilerin ilgisiz olması ve öğretim programının özünü kavrayamamalarından kaynaklanan zorluklar yaşandığı sonucuna ulaşılmıştır. Çalışmaların sonuçları birbirleriyle paralellik göstermektedir. 
Türkçe öğretmenleri, ders kitabından kaynaklı olarak en çok ders kitabının öğrencilerin seviyesine uygun olmaması (\%44) ve ders kitabı ve yazma etkinliklerinin tekdüze ve sıkıcı olmasının (\%32) yazma eğitimini olumsuz etkilediğini belirtmişlerdir. Bu sonuç Elma ve Bütün'ün (2015) araştırma sonuçlarıyla büyük oranda uyuşmaktadır. Söz konusu araştırmada öğretmenler genel olarak Türkçe Çalışma Kitabı'ndaki yazma etkinliklerinin öğrencilerin seviyesine uygun olmadığını, öğrencilerin kitaptaki etkinlikleri yaparken zorluk yaşadıklarını belirtmişlerdir. Yazma eğitimi için bir diğer olumsuzluk olarak da bazı öğretmenler, kitaplarda aynı tür yazma etkinliklerinin çok sık tekrar edildiği yönünde görüş bildirmişlerdir. Yaylı ve Solak'ın (2014) araştırmasında Türkçe öğretmenleri, Türkçe Ders Kitabı ve Öğretmen Kılavuz Kitabı'nın, programın gereklerini karşıladığını ve öğrencilerin seviyesine uygun olduğunu belirtmişlerdir. Söz konusu araştırma ile bu araştırmanın sonuçları birbiriyle örtüşmemektedir. Belirtilen araştırmada Öğretmen Kılavuz Kitabı'yla ilgili görüşlerin de ortaya konulması dolayısıyla değerlendirilen ders kitaplarının farklı yıllarda okutulan kitaplar olması söz konusu durumun olası nedenlerinden biri olarak düşünülebilir.

Türkçe öğretmenlerinin, ders saati ve müfredattan kaynaklı yazma eğitimini olumsuz etkileyen unsurlar olarak ders saatlerinin yazma becerisi için yetersiz olması (\%32) ile müfredat, hedef ve kazanımların çok fazla olmasını (\%20) gördükleri tespit edilmiştir. Araştırma sonuçları Solak'ın (2013) öğretmen görüşlerine dayanarak yaptığı araştırmanın sonuçlarıyla örtüşmektedir. Bu araştırmada öğretmenler yazma çalışmaları sırasında yaşadıkları zorluklar olarak zamanın yetersizliği, müfredatı yetiştirme kaygısı ve sınıf mevcudunun fazla olması gibi sebepleri öne sürmüşlerdir. Bununla birlikte müfredatın yoğun olmasının yazma eğitimi açısından olumsuzluk yaratması sonucuyla örtüşür nitelikteki Güven'in (2011) yaptığı araştırmada öğretmenlerin, öğrenme-öğretme süreçlerinde karşılaştıkları zorlukların başında etkinliklerin fazla olmasını gördükleri sonucuna ulaşılmıştır. Bilgin'in (2018) araştırma sonucunda bulunan yazmayı olumsuz etkileyen unsurlar arasında yazmaya ayrılan sürenin yetersiz olması sonucu da bu araştırmanın sonuçlarını destekler niteliktedir.

Türkçe öğretmenlerinin \%60' I LGS'de açık uçlu yazma becerisi sorusu sorulmamasının yazma eğitimini olumsuz etkilediği görüşündedirler. Özbay'a $(1997$, s. 16) göre test türü sınavlar Türkçe öğretiminde bilgi seviyesindeki ölçmede kullanılabilir. Fakat bir becerinin doğrudan doğruya ölçülmesi özellikle de yazılı ve sözlü anlatım becerisinin ölçülmesinde test tekniğinin kullanılması öğrencilerin yaratıcı yönlerini ortaya koymalarına ve bu yönlerini geliştirmelerine engel olmaktadır. Kurudayıoğlu'na $(2005$, s. 171) göre liseye geçiş sınavlarının test tekniğine dayalı olması nedeniyle öğrenciler yazılı anlatım becerisine fazla önem vermemekte bu nedenle de öğrencilerin yazma becerileri yeterince gelişememektedir. Özbay ve Kurudayıŏlu'nun bu tespitleri araştırma sonucunu destekler niteliktedir. Bununla birlikte yine araştırma sonuçlarına paralel olarak Özdemir'in (2008) yapmış olduğu araştırmada öğrencilerin liseye geçiş sınavlarında aldıkları başarı ile yazma becerisi başarıları arasında anlamlı bir ilişkinin olmadığı, bu nedenle test sistemine dayalı liseye geçiş sınavlarının öğrenciyi sadece bilgi yönünden ölçtüğü, yazma becerisi yönünden ölçmediği sonuçlarına ulaşılmıştır.

Türkçe öğretmenlerinin \%36'sının test yöntemine dayalı bir sınav ve eğitim sistemimizin olmasını yazma eğitimi için olumsuzluk olarak gördüğü tespit edilmiştir. Tok ve Ünlü'nün (2014) yapmış oldukları araştırmada ilkokul, ortaokul ve lise öğretmenlerinin, teste dayalı sınav sisteminin öğrencilerin yazma becerisini olumsuz etkilediği görüşünde oldukları saptanmıştır. Söz konusu araştırmanın sonucu, bu araştırmanın sonucuyla örtüşmektedir. Ayrıca Ungan'ın (2007, s. 468) öğrencileri test mantığına dayalı bir eğitimle yetiştirmenin onları düşünmeye ve üretmeye yöneltmekten ziyade test tekniğine yönlendirdiğini, bunun da yazma eğitimi önündeki en büyük engellerden biri olduğu yönündeki tespiti de bu araştırmadaki sonucu desteklemektedir.

Türkçe öğretmenlerinin \%12'si, bazı öğretmenlerin Türkçe eğitimini dil bilgisinden ibaret görmelerini öğretmenden kaynaklanan yazma eğitimi sorunu olarak belirtmişlerdir. Alanyazında bu sonucu destekler nitelikte bir örneğe rastlanmazken \%8'lik bir öğretmen grubunun dile getirdiği bazı öğretmenlerin kendini geliştirmemesinin yazma eğitimini olumsuz etkilediğine yönelik görüş ile Tağa ve Ünlü’nün (2013) çalışmasının sonuçları örtüşmektedir. Bu çalışmada yazma eğitiminde öğretmenden kaynaklı sorunlar arasında en çok öğretmenlerin alandaki gelişmeleri takip etmemeleri 
sonucuna ulaşılmıştır. Bununla birlikte çalışmamızda Türkçe öğretmenlerinin yazma eğitimini olumsuz etkileyen unsurlar arasında öğretmenlerden kaynaklı olarak çok az görüş bildirdikleri görülmüştür. Bu sonuç da yine Tağa ve Ünlü'nün (2013) çalışmasındaki sonuçlarla paralellik göstermektedir. Bu çalışmada öğretmenlerin öğretmenden kaynaklı yazma eğitimi sorunlarının fazla olmadığını düşündükleri ve bu konuda olumlu veya olumsuz değerlendirme yapmaktan kaçındıkları görülmüştür.

Öğrencilerin ilkokul eğitiminden kaynaklı yazma eğitimini olumsuz etkileyen unsurlar arasında Türkçe öğretmenlerinin \%28'i öğrencilere ilkokulda yazmanın yeterince öğretilememesini gösterirken \%16'sı ilkokulda yazma becerisinden çok test çözme becerisine önem verilmesine dikkat çekmektedir. Alanyazındaki birtakım çalışmalar bu sonucu desteklemektedir. Solak'ın (2013) yaptığı araştırmada öğretmenler, öğrencilerin yazma becerisinde zorluk yaşama nedenlerinden biri olarak ilkokul kademesinde yeterli yazma eğitimi almamalarını göstermektedirler. Tok ve Ünlü'nün (2014) araştırmasına göre ise ortaokul ve lise öğretmenleri ilkokul düzeyinde, öğrencilerin yazma becerisinin yeterince geliştirilememesinden, bu durumun da yazmayı olumsuz etkilemesinden yakınmaktadırlar.

Türkçe öğretmenlerinin $\% 40$ ’ lisans eğitimindeki yazma eğitimi uygulamalarının yetersiz olmasını öğretmenlerin yazma eğitimini olumsuz etkileyen, lisans eğitiminden kaynaklı bir unsur olarak görmektedir. Söz konusu öğretmenler ayrıca lisans süresince uygulamadan çok teorik bilgilerin öğretildiğini savunmaktadırlar. Öğretmenlerin \%20'si ise lisans eğitimindeki öğretmenlik uygulamalarının yetersiz olmasını yazma eğitimi için olumsuzluk olarak görmektedir. Lisans eğitimindeki yazma eğitimi uygulamalarının ve öğretmenlik uygulamalarının yetersiz olduğunu belirten öğretmenler bu uygulamaların yapıldığı ders saatinin az olduğunu düşünmektedirler. Bununla birlikte var olan derslerde yapılan söz konusu uygulamalar yetersiz olarak görülmektedir. Ayrıca Türkçe öğretmenlerinin \%16'sının görüşüne göre lisans sürecinde yazma eğitimiyle ilgili yeterli bilgisi ve okul tecrübesi olmayan öğretim elemanlarının yazma eğitimi dersini vermesi yazma eğitimini olumsuz etkilemektedir. Alanyazında bu sonuçları destekler nitelikte çalışmalar mevcuttur. Elma ve Bütün'ün (2015) yaptığı araştırmaya katılan öğretmenler, lisans eğitiminde uygulamadan çok teori üzerinde durulduğunu, bu nedenle mesleği mesleğin içinde öğrendiklerini dile getirmiştir. Bağcı'nın (2007) üniversite son sınıfta okuyan Türkçe öğretmeni adayları ile yaptığı araştırmada öğretmen adaylarının yazılı anlatımla ilgili ders sayısının ve haftalık ders saatinin yetersiz olduğunu düşündükleri, yazma becerisini kazandırma ve değerlendirme süreçlerinde kendilerini yetersiz gördükleri saptanmıştır.

Türkçe öğretmenlerinin görüşleri bütün olarak ele alındığında ise öğretmenlerin en çok LGS'de açık uçlu yazma becerisi sorusu sorulmaması (\%60), öğrencilerin yeterince kitap okumamaları (\%48), ders kitabının öğrencilerin seviyesine uygun olmaması (\%44), öğretmenlerin lisans eğitimindeki yazma eğitimi uygulamalarının yetersiz olması (\%40) ve test yöntemine dayalı bir sınav ve eğitim sistemimizin olmasının (\%36) yazma eğitimini olumsuz etkilediği düşüncesinde oldukları görülmüştür.

"Türkçe öğretmenlerine göre yazma becerisini geliştirebilmek için neler yapılabilir?" alt problemi kapsamında Türkçe öğretmenleri dokuz kategori altında toplanabilecek öneriler geliştirmiştir. Bu kategoriler "öğrenci; uygulama, etkinlik; aile, okul ve çevre; ders kitabı; ders saati ve müfredat; MEB ve eğitim sistemi; öğretmen; öğrencilerin ilkokul eğitimi; öğretmenlerin lisans eğitimi" olarak belirlenmiştir.

Öğretmenlerin, yazma becerisini geliştirebilmek için neler yapılması gerektiğine dair sundukları öneriler bütünüyle ele alındığında en çok "yazma eğitimi derslerinde daha fazla uygulama yapılabilir" (\%36), "öğrencileri güdüleyici, ödüllü yazma yarışmaları yapılabilir" (\%28), "ders kitabı birbirini tekrar etmeyen ilgi çekici etkinliklerle geliştirilebilir" (\%24), "LGS'de açık uçlu yazma becerisi sorusu sorulabilir" (\%24) ve "yazma becerisi için ayrı ve zorunlu bir ders konulabilir" (\%24) önerilerini dile getirdikleri saptanmıştır.

Araştırma sonucunda Türkçe öğretmenlerinin yazma eğitimini olumsuz etkileyen unsurlar bağlamında fazla görüş bildirmelerine karşın yazma becerisini geliştirmeye yönelik yapılabilecekler hakkında daha az görüş bildirdikleri görülmüştür. Bu durum öğretmenlerin yazma eğitimine dair sorunların fazlaca farkında oldukları, bu sorunlara getirilebilecek çözüm önerileri konusunda farklı bakış açılarına ve düşüncelere yeterince sahip olmadıkları şeklinde yorumlanabilir. 
Araştırma kapsamında görüşülen Türkçe öğretmenlerinin yazma eğitimini olumsuz etkileyen unsurlar ve yazma becerisini geliştirmeye yönelik yapılabilecekler hakkındaki görüşlerinin ayrıntılı olarak ortaya konulması, bu sorunların çözülmesine yönelik adımların atılması açısından önem arz etmektedir. Böylece araştırmanın yazma eğitimine ve öğrencilerin yazma becerilerinin gelişimine katkı sunacağı düşünülmektedir.

\section{Araştırma ve Yayın Etiği}

Bu çalışmada "Yükseköğretim Kurumları Bilimsel Araştırma ve Yayın Etiği Yönergesi" kapsamında uyulması belirtilen tüm kurallara uyulmuştur. Yönergenin ikinci bölümü olan "Bilimsel Araştırma ve Yayın Etiğine Aykırı Eylemler" başlığı altında belirtilen eylemlerden hiçbiri gerçekleştirilmemiştir.

\section{Etik Kurul izni}

Kurul adı = Gazi Üniversitesi Etik Komisyonu

Karar tarihi $=06.04 .2021$

Belge sayı numarası $=\mathrm{E}-77082166-302.08 .01-67340$

\section{Yazarların Katkı Oranı}

Bu makalenin hazırlanmasında her iki araştırmacının katkısı da \%50 oranında olmuştur.

\section{Çıkar Çatışması}

Bu çalışmada çıkar çalışması oluşturacak bir durum yoktur.

Aksan, D. (2020). Anlambilim. Ankara: Bilgi.

\section{Kaynaklar}

Akyol, H. (2000). Yazı Öğretimi. Milli Eğitim Dergisi, 146, 37-48.

Arıcı, A. F. ve Ungan, S. (2017). Yazılı anlatım el kitabı. Ankara: Pegem Akademi.

Arıcı, A. F. (2008). Üniversite öğrencilerinin yazılı anlatım hataları. Uludağ Üniversitesi Eğitim Fakültesi Dergisi, 21(2), 209-220.

Arıcı, A. F. ve Ungan, S. (2008). İlköğretim ikinci kademe öğrencilerinin yazılı anlatım çalışmalarının bazı yönlerden değerlendirilmesi. Dumlupınar Üniversitesi Sosyal Bilimler Dergisi, 20, 317328.

Aşılıoğlu, B. (1993). Ortaokullarda Türkçe öğretimi (Doktora tezi). Ankara Üniversitesi Sosyal Bilimler Enstitüsü, Ankara.

Bağcı, H. (2007). Türkçe öğretmeni adaylarının yazııı anlatıma ve yazılı anlatım derslerine yönelik tutumlarının değerlendirilmesi. TÜBAR, 21, 29-61.

Baltacı, A. (2017). Nitel veri analizinde Miles-Huberman modeli. Ahi Evran Üniversitesi Sosyal Bilimler Enstitüsü Dergisi, 3(1), 1-15.

Bilgin, S. (2018). Türkçe öğretmenlerinin Illköğretim Türkçe (6-8. Sınıflar) Öğretim Programı'nda yer alan yazma yöntem ve tekniklerini uygulama durumları (Yayımlanmamış yüksek lisans tezi). Mersin Üniversitesi Eğitim Bilimleri Enstitüsü, Mersin.

Büyüköztürk, Ş., Kılı̧̧ Çakmak, E., Akgün, Ö. E., Karadeniz, Ş. ve Demirel, F. (2014). Bilimsel araştırma yöntemleri. Ankara: Pegem Akademi.

Çelik, M. E. (2012). İlköğretim sekizinci sınıf öğrencilerinin yazılı anlatım becerilerinin farklı değişkenler açısından değerlendirilmesi. Turkish Studies, 7(1), 727-743.

Demir, T. (2013). Yazma becerisine yönelik kazanımların ortaokulda gerçekleşme düzeyi. Okuma Yazma Eğitimi Araştırmaları, 1(1), 45-56.

Deniz, E. (2017). Yedinci sınıf öğrencilerinin dil bilgisi, kelime bilgisi ve okuduğunu anlama düzeyleri ile yazma becerileri arasındaki ilişki (Doktora tezi). İnönü Üniversitesi Eğitim Bilimleri Enstitüsü, Malatya. 
Deniz, K. (2000). Yazılı anlatım becerileri bakımından köy ve kent beşinci sınıf öğrencilerinin durumu (Yayımlanmamış yüksek lisans tezi). Çanakkale Onsekiz Mart Üniversitesi Sosyal Bilimler Enstitüsü, Çanakkale.

Elma, C. ve Bütün, E. (2015). İlkokul ve ortaokul öğrencilerinin yazılı anlatım becerilerine ilişkin öğretmen görüşleri. Abant izzet Baysal Üniversitesi Eğitim Fakültesi Dergisi, 15(2), 104-131.

Göçer, A. (2015). Yazma çalışmalarını değerlendirme. M. Özbay (Ed.), Yazma eğitimi içinde (s. 199241). Ankara: Pegem Akademi.

Güneş, F. (2009). Türkçe öğretiminde günümüz gelişmeleri ve yapılandırıcı yaklaşım. Mustafa Kemal Üniversitesi Sosyal Bilimler Enstitüsü Dergisi, 6(11), 1-21.

Güney, N. (2016). Öğretmenlerin yazma eğitimine yönelik düşünceleri. Uluslararası Türkçe Edebiyat Kültür Eğitim (TEKE) Dergisi, 5(2), 970-985.

Güven, A. Z. (2011). İlköğretim İkinci Kademe Türkçe Dersi Öğretim Programı́na ilişkin öğretmen görüşleri. Buca Eğitim Fakültesi Dergisi, 29, 121-133.

İlaslan, B. (2007). Ortaöğretim ikinci sınıf öğrencilerinde görülen yazılı anlatım bozuklukları ve bu bozuklukların giderilmesi için çeşitli öneriler - Kalecik/Pursaklar örneği (Yayımlanmamış yüksek lisans tezi). Gazi Üniversitesi Eğitim Bilimleri Enstitüsü, Ankara.

Kırbaş, A. (2006). Illköğretim sekizinci sınıf öğrencilerinin yazılı anlatım becerilerinin değerlendirilmesi (Yayımlanmamış yüksek lisans tezi). Atatürk Üniversitesi Sosyal Bilimler Enstitüsü, Erzurum.

Kurudayıoğlu, M. (2005). Illköğretim II. kademe öğrencilerinin kelime hazinesi üzerine bir araştırma (Doktora tezi). Gazi Üniversitesi Eğitim Bilimleri Enstitüsü, Ankara.

Özbay, M. (1997). Test türü imtihanların Türkçe öğretimindeki yeri. Bilge, 11, 13-16.

Özbay, M. (2016). Türkçe özel öğretim yöntemleri II. Ankara: Öncü.

Özdemir, S. (2008). Ortaöğretim seçme sınavında başarılı olan öğrencilerin yazılı anlatım becerileri üzerine bir inceleme (Yayımlanmamış Yüksek Lisans Tezi). Gazi Üniversitesi Eğitim Bilimleri Enstitüsü, Ankara.

Solak, M. (2013). ilköğretim ikinci kademe Türkçe dersi çalışma kitaplarında ve öğretmen kılavuz kitaplarında yer alan yazma etkinliklerinin incelenmesi (Yayımlanmamış yüksek lisans tezi). Pamukkale Üniversitesi Eğitim Bilimleri Enstitüsü, Denizli.

Tağa, T. ve Ünlü, S. (2013). Yazma eğitiminde karşılaşılan sorunlar üzerine bir inceleme. Electronic Turkish Studies, 8(8), 1285-1299.

Tok, M. ve Ünlü, S. (2014). Yazma becerisi sorunlarının ilkokul, ortaokul ve lise öğretmenlerinin görüşleri doğrultusunda karşılaştırılmalı olarak değerlendirilmesi. Elektronik Sosyal Bilimler Dergisi, 13(50), 73-95.

Türnüklü, A. (2000). Eğitimbilim araştırmalarında etkin olarak kullanılabilecek nitel bir araştırma tekniği: görüşme. Kuram ve Uygulamada Eğitim Yönetimi, 24(24), 543-559.

Ungan, S. (2007). Yazma becerisinin geliştirilmesi ve önemi. Erciyes Üniversitesi Sosyal Bilimler Enstitüsü Dergisi, 23, 461-472.

Yaylı, D. ve Solak, M. (2014). Ortaokul Türkçe ders kitaplarında ve öğretmen kılavuz kitaplarında yer alan yazma etkinliklerine dair öğretmen görüşleri. Electronic Turkish Studies, 9(6), 1139-1151.

Yıldırım, A. ve Şimşek, H. (2018). Sosyal bilimlerde nitel araştırma yöntemleri. Ankara: Seçkin.

\section{Introduction}

\section{Extended Abstract}

The fact that humans are social beings brought with it the need to convey their feelings, thoughts and impressions to the person and group. The basic element of this transfer process is language. Language allows to convey feelings, thoughts and information to others, verbally and in writing. Reading and listening are receptive language skills whereas speaking and writing are expressive skills. In order for people to communicate effectively in society and maintain their social life, they must use each of the basic language skills correctly and effectively. Writing, which enables a person to express himself or herself in a written form, is a skill that should be taken seriously at every step of the education in this regard. 
Writing is the ability to regularly describe one's feelings, thoughts, impressions and dreams in a written form within the framework of certain rules. Although writing is regarded as a talent by some students and even teachers, it can be said that the writing process can be improved by researching, reading, writing a lot, correcting and rewriting (Aşılıoğlu, 1993, p. 138). In fact, this means that there can be a development through teaching writing, as in other skills. In this context, the necessity of teaching writing, which is organized within a certain plan and system, emerges. Teaching writing can be described as training given with various activities and feedbacks so that individuals can convey their feelings, thoughts and dreams in writing in an accurate, regular and meaningful way. Educational studies handled with the specified dimensions will bring students to a certain level in using their writing skills.

\section{Method}

The aim of the study was to determine the problems faced by secondary school Turkish teachers regarding teaching writing and to find solutions for these problems. For this purpose, phenomenological pattern, one of the qualitative research methods, was used in the research. The participants of the research are 25 Turkish teachers working at the Ministry of National Education. The study group was determined by "convenience sampling" among the purposive sampling methods. In addition, in order to increase the validity and reliability of the study, the sample were diversely selected. In this context, data source diversity was ensured by selecting teachers of different genders, ages and periods of service, working in different cities and settlements (province/district/rural area). A semi-structured interview form consisting of two questions was used to take the opinions of the participants. The findings were analysed through content analysis and presented in categories.

In order to ensure the validity and reliability of the research, expert opinion was taken from 3 subject matter experts before applying the semi-structured interview form. Necessary corrections were made in the interview questions in line with the expert opinions. Afterwards, pilot interviews were conducted with 3 teachers, and interview form was put into final form. In order to ensure the validity and reliability of the coding made during data analysis, coding was done by 2 different experts. $80 \%$ and above agreement rate of coders indicates that the coding is reliable (from Miles \& Huberman, 1994 and Patton, 2002 as cited in Baltacı, 2017). According to coding reliability formula of Miles and Huberman, the agreement between coders was calculated as $97.13 \%$. Based on this result, it can be said that the coding are valid and reliable.

\section{Result and Discussion}

As a result of the findings of the research; the factors that negatively affect the teaching writing process are "student; family, school and environment; textbook; lesson duration and curriculum; Ministry of National Education and education system; teacher; primary education of students; undergraduate education of teachers". When all categories are examined, $60 \%$ of the teachers cited lack of open-ended questions about writing in LGS (High School Entrance Exam), $48 \%$ of them cited students' inabilities to read books, $44 \%$ of them cited the cookbooks' unsuitability for the level of the students, $40 \%$ of the teachers cited the lack of practice in writing in undergraduate education, and finally $36 \%$ of the teachers cited multiple choice test based exam and education system as negative factors.

The suggestions made by the teachers to improve teaching writing were gathered in nine different categories as follows "student; application, activity; family, school and environment; textbook; lesson duration and curriculum; Ministry of National Education and education system; teacher; primary education of students; undergraduate education". 28\% of Turkish language teachers suggested that in order to improve teaching writing, within the scope of the activity category, writing prize competitions, which motivate students, can be organised, $16 \%$ of teachers suggested that writers and poets can be invited to school to share their experiences, and $16 \%$ of them suggested that doing writing exercises after a trip and nature walk can be done. Within the 
scope of family, school and environment category, $8 \%$ of Turkish teachers think that strengthening school and family interaction can improve teaching writing.

$24 \%$ of Turkish teachers stated that within the scope of the course book category, the course book should be developed with interesting activities that do not repeat each other, $20 \%$ of them said that coursbooks should include texts and activities more appropriate to the level of the students, and $8 \%$ of the teachers think that publishing a sample writing training activity would improve their writing skills. Within the scope of lesson duration and curriculum, 20\% of Turkish teachers suggested that increasing Turkish lesson hours, and $8 \%$ of them suggested reducing the content of Turkish Curriculum and attainments can promote writing skill.

$24 \%$ of Turkish teachers stated that in order to improve writing education within the scope of Ministry of National Education and education system category, open-ended writing skill questions should be asked in LGS, and $24 \%$ stated that a separate and compulsory course should be included for writing skill. In order to improve teaching writing in the teacher category, $8 \%$ of Turkish teachers suggested that teachers can be trained with various courses on writing skills, and $8 \%$ suggested that teachers from other branches can give more importance to writing skills.

$8 \%$ of Turkish teachers think that giving more importance to students' writing skills starting from primary school within the scope of primary school education can improve their writing education. Within the scope of the undergraduate education of the teachers, it was determined that $36 \%$ of Turkish teachers cited doing more practice in writing education courses, $16 \%$ of teacher cited increasing the quality and number of teaching practice courses, and $12 \%$ cited teaching by expert teachers in teaching writing as factors that can improve teaching writing.

When the suggestions given by the teachers about what should be done to improve writing skills are taken into consideration, the following topics stand out: More practices can be done in writing education lessons (36\%); writing prize competitions can be organized to motivate students (28\%); the coursebook can be improved with interesting non-repetitive activities (24\%); in High School Entrance Exam (LGS), an open-ended writing skill question can be asked (24\%); a separate and compulsory course can be given for writing skills (24\%). As a result of the research, it was seen that although Turkish teachers expressed more opinions about the factors that negatively affect teaching writing, they expressed less opinions about what can be done to improve writing skills. This situation can be interpreted as teachers are highly aware of the problems related to teaching writing but they are insufficient in suggesting solutions to these problems. 